ISSN (Print) : :1412-7601

ISSN (Online) : 2654-8712

Volume 6, No.1 Maret 2020

EKONOBIS

http://www.ekonobis.unram.ac.id

\title{
Implikasi Penjualan Padi Sistim Tebasan Dan Dampaknya Tehadap Kegiatan Zakat Infaq Dan Sadaqah Di Kabupaten Lombok Barat
}

\author{
Akhmad Jupri, M.Huzaini, Sahri. \\ Universitas Mataram
} ARTICLE INFO

Keywords :

Rice, Slash, Zakat

ABSTRACT : Farmers sell rice with a slash system is an effort to get income faster in order to meet their daily needs. On the other hand every Muslim farmer who has fulfilled the requirements and the zakat ratio is obliged to issue zakat on the results of his farming. The fact is that not all farmers issue zakat on the results of their farming. This study aims to analyze the reasons farmers sell their rice using the slash system and the impact of the sale on the obligation to issue zakat, infaq and sadaqah in West Lombok Regency. This study uses a qualitative approach to the type of field study research. Data collection techniques carried out by observation and in-depth interviews. The informant is determined by snowball sampling technique. Data were analyzed descriptively. The conclusions of this study provide the description that various reasons farmers sell their rice with a slash system for various reasons, namely not having a drying floor, having no storage, limited harvest costs, expensive harvest costs, wanting to quickly earn an income, no time to take care of the harvest and farmers feel busy handling postharvest. Not all farmers issue zakat from rice production and not all farmers who issue zakat issue zakat in accordance with the provisions of agricultural zakat. It is recommended that religious leaders through the Zakat Charity Agency at the Village Level (BAZDES) conduct counseling on the obligation of rice zakat to farmers.

Kata Kunci :

Padi, Tebasan, Zakat

ABSTRAK: Petani menjual padi dengan sistim tebasan merupakan upaya untuk mendapatkan penghasilan lebih cepat guna dapa memenuhi kebutuhan hidupnya. Disisi lain setiap petani muslim yang telah memenuhi persayaratan dan nisab zakat diwajibkan mengeluarkan zakat atas hasil usahataninya. Faktanya tidak semua petani mengeluarkan zakat atas hasil usahataninya. Penelitian ini bertujuan untuk menganalisis alasan petani menjual padinya dengan sistim tebasan dan dampak penjualan tersebut terhadap kewajiban mengeluarkan zakat, infaq dan sadaqah di Kabupaten Lombok Barat. Penelitian ini menggunakan pendekatan kualitatif dengan jenis penelitian studi lapangan. Teknik pengumpulan data dilakukan dengan cara observasi dan wawancara mendalam. Informan ditentukan dengan teknik snowball sampling. Data dianalisis secara deskriptif. Kesimpulan penelitian ini memberikan diskripsi bahwa berbagai alasan petani menjual padinya dengan sistim tebasan dengan berbagai alasan, yaitu tidak memiliki lantai jemur, tidak memiliki tempat penyimpanan, keterbatasan biaya panen, ongkos panen mahal, ingin cepat mendapatkan penghasilan, tidak ada waktu mengurus panen dan petani merasa sibuk menangani pasca panen. Tidak semua petani mengeluarkan zakat hasil produksi padi dan petani yang mengeluarkan zakat tidak semuanya mengeluarkan zakat sesuai dengan ketentuan zakat pertanian. Direkomendasi bahwaTokoh agama melalui Badan Amal Zakat di Tingkat Desa (BAZDES) melakukan penyuluhan kewajiban zakat padi kepada para petani.

Corresponding Author :

Alamat : Program Studi Ekonomi Pembangunan, Fakultas Ekonomi dan Bisnis, Universitas Mataram, Jln. Majapahit No. 62 Mataram.

e-mail: Jufi.akhmad@gmail.com 


\section{Latar Belakang}

Lombok Barat merupakan salah satu Kabupaten yang ada di Daerah Nusa Tenggara Barat. Sektor pertanian di kabupaten Lombok Barat masih dominan, yaitu menyumbang 20,55 persen terhadap pembentukan Produk Domestik Regional Bruto (PDRB) Lombok Barat. Ini mencerminkan masih tingginya penduduk yang menggantungkan hidupnya dari sektor pertanian, yaitu sebanyak 172.384 orang dari 675.222 jumlah penduduk yang bekerja atau sebesar 25,53 persen dari keseluran penduduk (Kabupaten Lombok Barat dalam Angka, 2017). Adapun Kecamatan yang mempunyai peran penting dalam menopang sektor pertanian yang ada di Kabupaten Lombok Barat adalah Kecamatan Lingsar dan Labuapi.

Kegiatan pertanian tanaman pangan merupakan mata pencaharian pokok dan ditekuni secara turun temurun bagi sebahagian besar penduduk di wilayah Kabupaten Lombok Barat. Petani di wilayah ini sebagian besar termasuk dalam katagori petani gurem dalam arti sebagian besar petani menggarap lahan dibawah 0,50 ha dan umumnya merupakan warisan dari orang tua mereka.

Dari hasil pengamatan yang dilakukan, para petani dalam kegiatan pertaniannya tidak kesulitan untuk mendapatkan air, karena air sepanjang tahun, sehingga kapan saja mereka membutuhkan air tetap tersedia setiap saat. Implikasi dari kondisi diatas adalah pola tanam yang dilakukan oleh para petani menjadi tidak teratur, dalam arti kapan saja mereka mau menanam padi tidak ada hambatan.

Penanaman padi secara terus menerus atau berulang-ulang akan memicu berkembangnya organisme pengganggu tanaman baik hama patogen maupun gulma karena berada dalam lingkungan yang tidak banyak mengalami perubahan. Hal ini menjadi salah satu penyebab munculnya hama wereng yang dapat menimbulkan kegagalan panen (Setiawan, 2011:2).

Fenomena penjualan hasil produksi padi dilakukan setelah panen di sawah dalam bentuk sawah kering secara tebasan. Hanya sebagian kecil petani yang menjual dalam bentuk kering giling. Berbagai alasan petani menjual produksi padinya baik kering sawah, tebasan 
maupun kering giling. Model penjualan ini berpengaruh terhadap kewajiban mengelurakan zakat dan anjuran mengeluarkan infaq dan sadaqah.

Zakat merupakan salah satu ajaran Islam yang sifatnya melanjutkan (Fakhruddin, 2008 :1) dan juga sebuah kewajiban yang harus ditunaikan, tak ada seorang muslimpun membantahnya. Sebab dalil-dalil yang menjelaskan kewajiban zakat sangat jelas. Hanya saja, jika dibandingkan dengan pelaksaan shalat, praktek pelaksanaan zakat dalam kehidupan kaum muslimin masih jauh tertinggal. Banyak faktor yang menjadi penyebabnya. Diantaranya adalah akibat minimnya pemahaman mereka mengenai kewajiban zakat. Dalam al-Qur'an, zakat seringkali digandeng penyebutannya dengan shalat, sebagaimana termuat dalam surat al-Baqarah ayat 43 , yang berbunyi "Dan laksanakanlah shalat, tunaikanlah zakat dan rukuklah besera orang orang yang rukuk (Depatemen Agama RI, 2011:10)

Hal ini menunjukkan bahwa zakat mempunyai kaitan yang erat dengan shalat, meskipun terdapat perbedaaan antara keduanya. Zakat adalah suatu ibadah maliyah yang lebih menjurus kepada aspek sosial kemasyarakatan (ijtima'iyah), Sedangkan shalat lebih menjurus kepada kepribadian yang mulia yang bersifat personal (fardiyah). Oleh karena itu, kewajiban mengeluarkan zakat ini setara dengan kita melaksanakan shalat lima waktu.

Adanya berbagai perbedaan kemampuan petani di Kabupaten Lombok Barat dalam memenuhi kebutuhan hidup sehari-hari bagi diri dan keluarganya, mendorong beberapa petani untuk menjual produksi padi sistim tebasan. artinya menjual padi sebelum dipanen pada areal persawahannya. Penelitian Cahyani (2010) menyimpulkan bahwa terdapat beberapa faktor yang mempengaruhi transaksi jual beli secara tebasan, yaitu transaksinya lebih mudah, tidak berbelit-belit, lebih efektif karena tidak perlu repot memanen, hemat biaya serta pembayarannya dilakukan diawal. Demikian pula hasil penelitian Nizar (2012) menyimpulkan bahwa akad jual beli mendong secara tebasan di Kelurahan Cibeureum Kota Tasikmalaya dapat diterima menurut Hukum Islam karena telah memenuhi semua rukun dan syaratnya serta sejalan dengan maqasyid asy-syariah, yaitu untuk keadilan dan kemaslahatan seluruh umat manusia dengan memberikan salah satu kemudahan dalam memenuhi kebutuhan hidupnya. 
Sistim jual tebasan bagi petani di Kabupaten Lombok Barat dianggap sebagai pilihan untuk cepat mendapatkan penghasilan atas usahataninya. Disamping adanya berbagai keterbatasan petani dalam membiayai panen dan keterbasan fasilitas untuk melakukan kegiatan pasca panen. Petani yang mengusahakan lahan padi relatif luas, yaitu diatas 1 ha memilih menjual produksi padinya setelah panen.

Penghasilan yang diperoleh petani muslim dari produksi usahataninya terdapat kewajiban mengeluarkan zakat pertanian selama memenuhi nisab produksi sebanyak minimal sebanyak 653 kilo gram gabah atau setara 520 kilo gram beras. Hal terlepas dari sistem penjualan yang dilakukan petani, baik menjual sistim tebasan atau menjual setelah panen. Faktanya tidak semua petani muslim di Kabupaten lombok Barat mengeluarkan zakat terhadap produksi padinya. Hal ini dipengaruhi oleh berbagai hal seperti pengetahuan terhadap kewajiban mengeluarkan zakat padinya, keengganan mengeluarkan zakat dan pengaruh lingkungan sesama petani. Bambang (2019) menyimpulkan bahwa tingkat pendidikan dan pengetahuan signifikan mempengaruhi kepatuhan membayar zakat pendapatan pada petani kentang di
Desa Kersik Tuo Kecamatan Kayu Aro Kabupaten Kerinci Jambi.

Berdasarkan uraian diatas, disusun studi yang berjudul"Implementasi Penjualan Padi Sistim Tebasan dan Dampaknya terhadap Kegiatan Zakat Infaq dan Sadaqah di Kabupaten Lombok Barat", dengan rumusan masalah "mengapa dan bagaimana petani di Kabupaten Lombok Barat menjual padinya dengan sistim tebasan dan apakah petani telah melaksanakan kewajiban mengeluarkan zakat produksi pertanian secara syar'i dan anjuran mengeluarkan infaq dan sadaqah".

Tujuan studi ini untuk menganalisis alasan dan bagaimana petani menjual padinya dengan sistim tebasan dan dampak penjualan tersebut terhadap kewajiban mengeluarkan zakat, infaq dan sadaqah di Kabupaten Lombok Barat.

\section{TINJAUAN PUSTAKA}

Jual beli berasal dari segi etimologis adalah menukar harta dengan harta. Sedangkan pengertian dari istilah adalah menukar suatu barang engan barang yang lain dengan cara tertentu (akad). (Rasyid, 2005 : 84-85). Pengertian sebenarnya dari kata "bay'un"(jual) itu ialah pemilikan harta dengan harta (barang dengan barang) dan agama menambahkan saling 
rela (suka sama suka). Ada yang mengatakan bahwa "jua" itu ialah ijab qabul (peneyerahan dan penerimaan dalam transaksi), sesuai firman Allah SWT dalam surat An Nisa' ayat 29 "tijaratan antaradiin" yang berarti perniagaan yang terjadi suka sama suka.

Menurut As Shan'ani (1995 : 90), kebutuhan manusia tergantung pada apa yang ada pada orang lain (temannya); sedangkan temannya itu terkadang tidak mau memberikannya kepada orang lain. Sedangkan menurut Al Jazairi (2000 : 116), hikmah disyariatkan jual beli ialah seorang muslim bisa mendapatkan apa yang dibutuhkan dengan sesuatu yang ada di tangan saudaranya tanpa kesulitan yang berarti. Maka dalam syarat jual beli itu terdapat sarana untuk sampai kepada maksud itu,tanpa dosa.

Muslich (2006: 151-152) dalam bukunya "Fiqh Muamalah" menjelaskan beberapa pengertian jual beli :

1. Menurut Hanafiyah, jual beli dalam arti khusus yaitu menukar benda dengan dua mata uang (emas dan perak) dan semacamnya, atau tukar menukar uang dengan barang menurut cara yang khusus. Jual beli dalam arti umum adalah tukarmenukar harta dengan harta menurut cara yang khusus, harta mencakup zat (barang) atau uang.

2. Menurut Malikiyah, jual beli dalam arti umum adalah jual beli adalah akad mu"awadlah (timbal balik) atas selain manfaat dan bukan pula untuk menikmati kesenangan. Sedangkan dalam arti khusus jual beli adalah akad mu"awadlah (timbal balik) atas selain manfaat dan bukan pula untuk menikmati kesenangan, bersifat mengalahkan salah satu imbalannya bukan emas dan bukan perak, obyeknya jelas dan bukan utang.

3. Menurut Syafi"iyah jual beli menurut syara" adalah suatu akad yang mengandung tukar menukar harta dengan harta dengan syarat yang akan diuraikan nanti untuk memperoleh kepemilikan atas benda atau manfaat untuk waktu selamanya.

4. Hanabilah memberikan definisi jual beli sebagai berikut jual beli menurut syara'" adalah tukar-menukar harta dengan harta, atau tukar-menukar manfaat yang mubah dengan manfaat yang mubah untuk waktu selamanya, bukan riba dan bukan utang.

Dari beberapa definisi di atas dapat disimpulkan bahwa pertama, jual beli adalah akad mu'awadlah yakni akad yang 
dilakukan oleh dua pihak, dimana pihak pertama menyerahkan barang dan pihak kedua menyerahkan imbalan, baik berupa uang maupun barang. Kedua, Syafi"iyah dan Hanafiah mengemukakan bahwaobjek jual beli bukan hanya barang (benda), tetapi juga manfaat, dengan syarat tukar-menukar berlaku selamanya, bukan untuk sementara. Jadi, jual beli merupakan akad yang dilakukan oleh dua pihak yang bertujuan saling menguntungkan dengan cara-cara menurut syariat Islam.

\section{Landasan jual beli}

Jual beli disyari'atkan berdasarkan alQur'an, sunah dan ijma' yakni :

\section{Al-Qur'an}

Allah SWT berfirman dalam Al-Qur'an, Surat Al-Baqarah [2] Ayat 275 :

"Orang-orang yang memakan riba tidak dapat berdiri melainkan seperti berdirinya orang yang kemasukan syaitan karena gila. Yang demikian itu karena mereka berkata bahwa jual beli itu sama dengan riba. Padahal Allah telah menghalalkan jual beli dan mengharamkan riba. Barang siapa yang mendapat peringatan dari Tuhannya, lalu dia berhenti maka apa yang telah di[erolehnya daluhu menjadi miliknya dan urusannya (terserah) kepada Allah. Barang siapa yang mengulangi maka mereka itu adalah penghuni neraka; mereka kekal di dalamnya". (Departemen Agama RI, 2011:10)

Juga dalam surat an-nisa' [4] ayat 29 Allah SWT juga berfirman,

"Wahai orang-orang yang beriman, janganlah kamu saling memakan harta sesamamu dengan jalan yang batil (tidak benar), kecuali dalam perdagangan yang berlaku atas dasar suka sama suka di antara kamu. Dan janganlah kamu membunuh dirimu. Sungguh Allah adalah Maha Penyayang kepadamu.". (Departemen Agama RI, 2011:140-141 ).

\section{As-Sunnah}

Rasulullah SAW yang bersabda yang diriwayatkan oleh Imam Ahmad:

"Rafi' bin Khadij berkata: Rasulullah SAW ditanya tentang mata pencaharian yang paling baik. Beliau menjawab, "Seseorang yang bekerja dengan tangannya dan setiap jual-beli yang mabrur".(HR. alBazzar dinyatakan shahih oleh al-Hakim an-Nasyaburi).

Maksud mabrur dalam hadits di atas adalah jual-beli yang terhindar dari usaha tipu-menipu dan merugikan orang lain. Rasulullah SAW sangat melarang sikap dan prilaku negative dalam aktivitas jualbeli, di antaranya adalah: pertama, jualbeli dengan penipuan. Penipuan dapat merugikan orang lain dan melanggar hak asasi jual-beli yaitu suka sama suka. Orang 
yang tertipu jelas tidak akan suka karena haknya dikurangi atau dilanggar.jual-beli dengan penipua adalh jual beli yang tidak diketahui hasilnya, atau tidak bisa di serah terimakan, atau tidak diketahui hakikat dan kadarnya, misalnya jual-beli burung yang masih berada diangkasa jual beli anak hewan yang masih di dalm kandungan induknya, dan termasuk juga jual-beli Tebasan karean hakikat dan kadarnya tidak jelas atau tidak diukur (Idri, 2016 : 159).

\section{3. ljma' ulama}

Ulama telah sepakat bahwa jual beli diperbolehkan dengan alasan bahwa manusia tidak akan mencukupi kebutuhan dirinya, tanpa bantuan orang lain. Namun demikian, bantuan atau barang milik orang lain yang dibutuhkannya itu, harus diganti dengan barang lainnya yang sesuai. (Syafi'i, 2001: 74-75).

Ulama muslim sepakat (ijma') atas kebolehan akad jual beli. ljma' ini ini memberikan hikmah bahwa, kebutuhan manusia berhubugan dengan sesuatu yang ada dalam kepemilikan orang lain, dan kepemilikan sesuatu itu tidak akan diberikan dengan begitu saja, namun terdapat kompensasi yang harus diberikan. Dengan disyariatkannya jual beli merupakan salah satu cara untuk merealisasikan keinginan dan kebutuhan manusia, karena pada dasarnya, manusia tidak bisa hidup tanpa hubungan dan bantuan orang lain (Djuwaini, $2008: 73$ ).

Dari kandungan ayat-ayat Allah SWT dan sabda-sabda Rasul SAW diatas, para ulama fiqh mengatakan bahwa hokum asal dari jual beli adalah mubah (boleh).Akan tetapi pada situasi-situasi tertentu menurut imam asy-syatibi pakar fiqh malikiyah, hukumnya boleh berubah menjadi wajib.Imam asy-syatibi memberikan contoh ketika terjadi praktik monopoli atau ihtikar, dimana adanya penimbunan barang sehingga stok hilang dari pasar dan harga melonjak naik).Apabila seseorang melakukan monopoli atau ihtikar dan mengakibatkan melonjaknya harga barang yang ditimbun dan disimpan itu, maka menurutnya pedagang itu wajib menjual barangnya sesuai dengan harga sebelum terjadinya pelonjakan harga.Dalam hal ini, pedagang itu wajib menjual barangnya sesuai dengan ketentuan pemerintah.Hal ini sesuai dengan prinsip asy-syatibi bahwa yang mubah itu apabila sekelompok pedagang besar melakukan boikot tidak mau menjual beras lagi, pihak pemerintah boleh memaksa mereka untuk berdagang beras dan para pedagang ini wajib melaksanakannya. Demikian pula pada 
komoditi-komoditi lainnya (Harun, 2008 : 114).

\section{Rukun dan Syarat Jual Beli}

\section{Rukun jual beli}

Syafi'i (2001:74-75) memaparkan rukun jual beli ada tiga, yaitu:

1. Pelaku transaksi yaitu penjual dan pembeli.

2. Objek trannsaksi, yaitu harga dan barang.

3. Akad (transaksi), yaitu segala tindakan yang dilakukan kedua belah pihak yang menunjukan mereka sedang melakukan transaksi, baik tindakan itu berbentuk kata-kata maupun perbuatan.

Menurut kompilasi hukum ekonomi syariah, rukun jual beli ada tiga, yaitu:

\section{Pihak-pihak.}

Pihak-pihak yang terkait dalam perjanjian jual beli terdiri atas penjual, pembeli dan pihak lain yang terlibat dalam dalam perjanjian tersebut.

\section{Objek.}

Objek jual beli terdiri atas benda yang berwujud dan benda yang tidak berwujud, yang bergerak maupun benda yang tidak bergerak, dan yang terdaftar maupun yang tidak terdaftar. Syarat objek yang diperjual belikan adalah sebagai berikut: barang yang dijual belikan harus ada, barang yang dijual belikan harus dapat diserahkan, barang yang dijual belikan harus berupa barang yang memiliki harga/nilai tertentu, barang yang dijual belikan harus halal, barang yang dijual belikan harus diketahui oleh pembeli, penu jukan dianggap memenuhi syarat langsung oleh pembeli tidak memerlukan penjelasan lebih lanjut, dan barang yang dijual harus ditentukan secara pasti pada waktu akad.

\section{Kesepakatan.}

Kesepakatan dapat dilakukan dengan tulisan, lisan dan isyarat, ketiganya mempunyai makna hukum yang sama.

Ada dua bentuk akad menurut kompilasi ekonomi syari'ah, yaitu:

a. Akad dengan kata-kata, dinamakan juga dengan ijab Kabul. ljab, yaitu kata-kata yang diucapkan terlebih dahulu. Misalnya: penjual berkata: "baju ini saya jual dengan harga $\mathrm{Rp}$. 10.000,-. Kabul, yaitu kata-kata yang diucapkan kemudian. Misalnya: pembeli berkata: "barang saya terima".

b. Akad dengan perbuatan, dinamakan juga dengan mu'athah. Misalnya: pembeli memberikan uang seharga Rp 10.000,- kepada penjual, kemudian mengambil barang yang senilai itu tanpa terucap kata-kata dari kedua belah pihak. 


\section{Syarat Jual Beli}

Syafi'i (2001 : 76) syarat-syarat jual beli, yaitu :

1. Saling rela antara kedua belah pihak. Kerelaan antara kedua belah pihak untuk melakukan transaksi syarat mutlak keabsahannya, berdasarkan firman allah SWTdalam QS. An-nisaa' (4): 29, dan hadis Nabi Riwayat Ibnu Majah: "jual beli haruslah atas dasar kerelaan (suka sama suka)."

2. Pelaku akad adalah orang yang dibolehkan melakukan akad, yaitu orang yang telah baligh, berakal, dan mengerti. Maka, yang dilakukan oleh anak kecil, orang gila, atau idiot tidak sah kecuali dengan seizinwalinya, kecuali akad yang bernilai rendah seperti membeli kembang gula, korek api, dan lain-lain. Hal ini berdasarkan firman Allah SWT QS.An-nisa' (4): 5 dan 6).

3. Harta yang menjadi objek transaksi telah dimiliki sebelumnya oleh kedua belah pihak. Maka, tidak sah jual beli barang yang belum dimiliki tanpa seizin pemiliknya. Hal ini berdasarkan Hadist Nabi SAW Riwayat Abu Daud dan Tirmidzi, sebagai berikut: "janganlah engkau jual barang yang bukan milikmu."

4. Objek transaksi adalah barang yang dibolehkan dalam islam. Maka tidak boleh menjual barang haram seperti khamar dan lainlain. Hal ini berdasarkan Hadist Nabi SAW Riwayat Ahmad: "sesungguhnya Allah bila mengharamkan suatu barang juga mengharamkan nilai jual barang tersebut".

5. Objek transaksi adalah barang yang bisa diserahterimakan. Maka tidak sah jual mobil hilang, burung yang angkasa dsb, karena tidak dapat diserahterimakan. Hal ini berdasarkan Hadist Nabi SAW Riwayat Muslim: "Dari Abu Hurairah r.a. bahwa Nabi Muhammad SAW melarang jual beli gharar (penipuan)".

6. Objek jual beli diketahui oleh kedua nbelah pihak saat akad. Maka tidak sah menjual barang yang tidak jelas. Misalnya, pembeli harus melihat barang tersebut dan/atau spesifikasi barang tersebut.Hal ini berdasar Hadist Riwayat Muslim tersebut.

7. Harga harus jelas saat transaksi. Maka tidak sah jual beli dimana 
penjual mengatakan "aku jual mobil ini kepadamu dengan harga yang kita sepakati nantinya."

\section{Pandangan Ulama Tentang Jual Beli Tebasan (Juzaf)}

Didalam As-Sunnah terdapat beberapa hadits yang menunjukkan disyariatkannya jual beli tebasan/juzaf, diantaranya adalah dua hadits berikut :

1. Diriwayatkan oleh Imam Muslim dan Nasa'i dari Jabir ra ia berkata, Rasulullah melarang untuk transaksi sejumlah (subrah) kurma yang tidak diketahui takarannya dengan kurma yang diketahui takarannya. Pada hadits ini terdapat dalil yang menunjukkan bahwa boleh membeli kurma secara tebasan/juzaf, apabila alat pembayarnya berasal dari barang selain kurma.Apabila alat pembayarannya juga kurma, maka jual beli itu menjadi haram karena mengandung riba fadl. Hal itu karena jual beli sesuatu barang sejenisnya sedangkan salah satu diantara keduanya tidak diketahui kadarnya adalah haram.Tidak diragukan lagi bahwa tidak mengetahui salah satu alat tukar atau keduanya menjadi peluang diperkirakan terjadinya kelebihan atau kekurangan. Segala sesuatu yang memungkinkan terjadinya sesuatu yang haram maka wajib untuk dijauhi. Sudah menjadi hal yang diketahui bahwa kurma termasuk kedalam kategori komoditas ribawi.

2. Dalam hadits riwayat Tirmidzi dan Ibnu Majah dari Ibnu Umar ra., ia berkata, mereka (masyarakat) melakukan transaksi makanan secara juzaf diujung pasar (tempat yang jauh dari pasar), kemudian Rasulullah melarang mereka untuk menjualnya sehingga mereka memindahkan (dari tempat) nya.

Sisi pengambilan hukum dari hadits ini, adalah bahwa jual beli tebasan merupakan salah satu sistem jual beli yang dilakukan oleh para sahabat pada zaman Rasulullah SAW dan beliau tidak melarangnya. Hanya saja, beliau melarang untuk menjualnya kembali sampai memindahkannya dari tempat semula.Ini merupakan taqriri (persetujuan) beliau atas bolehnya jual beli tebasan. Seandainya terlarang, pasti Rasulullah SAW akan melarangnya dan tidak menyatakan hal di atas. Dalam hal ini para fuqaha juga menyatakan diperbolehkannya jual beli tebasan meskipun keduanya tidak mengetahui kadar tanaman saat melakukan akad, baik berupa makanan, pakaian maupun hewan.

Ulama fiqh madzhab Malikiyyah menyebutkan 7 syarat bagi keabsahan jual beli juzaf sebagaimana hal ini ditemukan 
dalam pendapat ulama madzhab lain. Syarat dimaksud adalah sebagai berikut :

1. Objek transaksi harus bisa dilihat. Ulama hanafiyah, syafiiyyah dan hanabilah setuju terhadap syarat ini.

2. Penjual dan pembeli tidak mengetahui secara jelas kadar objek jual beli, baik dari segi takaran, timbangan maupun hitungannya. Imam Ahmad menyatakan, jika penjual mengetahui kadar objek transaksi, maka ia tidak perlu menjualnya secara juzaf.

3. Jual beli dilakukan atas sesuatu yang dibeli secara partai, bukan per satuan. juzaf diperbolehkan atas sesuatu yang bisa ditakar atau ditimbang, seperti biji-bijian dan sejenisnya. Jual beli juzaf tidak bisa dilakukan atas pakaian, kendaraan yang dapat dinilai per satuannya. Berbeda dengan barang yang nilainya sangat kecil per satuannya, atau memiliki bentuk yang relatif sama. Seperti telur, apel, mangga, semangka, kurma, dan sejenisnya.

4. objek transaksi bisa ditaksir oleh orang yang memiliki keahlian dalam penaksir. Akad juzaf tidak bisa dipraktikkan atas objek yang sulit ditaksir.Madzhab Safiiyyah sepakat atas adanya syarat ini

5. Objek akad tidak boleh terlalu banyak, sehingga sangat sulit ditaksir, namun juga tidak terlalu sedikit, sehingga sangat mudah diketahui kuantitasnya.

6. Tanah yang digunakan sebagai tempat penimbunan objek transaksi haruslah rata, sehingga kadar objek transaksi bisa ditaksir.

7. Tidak diperbolehkan mengumpulkan jual beli barang yang diketahui kadarnya secara jelas, dengan barang yang diketahui kadarnya secara jelas, dalam satu akad. Misalnya, jual beli kurma satu kilo, dikumpulkan dengn apel yang berada dalam satu pohon, dengan satu harga atau dua harga.

\section{Khiyar dalam Jual Beli}

Menurut ulama fiqih pengertian khiyar adalah suatu keadaan yang menyebabkan aqid memiliki hak untuk memutuskan akadnya (menjadikan atau membatalkannya) jika khiyar tersebut berupa khiyar syariat, aib, atau ru'yah, atau hendaklah memilih di antara dua barang jika khiyar ta'yin (Syafi'i 2001: 103). Fungsi khiyar menurut Syara' adalah 
agar kedua orang yang berjual beli dapat memikirkan dampak positif atau negatif masing-masing dengan pandangan ke depan, supaya tidak terjadi penyesalan dikemudian hari yang disebabkan merasatertipu atau tidak adanya kecocokan dalam membeli barang yang telah dipilih (Sahrani dan Abdullah 2011: 76).

Khiyar terbagi menjadi tiga, yaitu khiyar majlis, khiyar syarat dan khiyar berikut ini adalah urainnya.

\section{Khiyar Majlis}

Khiyar majlis artinya antara penjual dan pembeli boleh memilih akan melanjutkan jual beli atau membatalkannya. Selama keduanya masih ada dalam satu tempat majlis), khiyar majlis dapat dilakukan dalam berbagai jual beli, Rasulallah saw, bersabda: "Penjual dan Pembeli boleh khiyar selama belum berpisah" (H.R Bukhari dan Muslim). Bila keduanya telah berpisah dari tempat akad tersebut, maka khiyar majlis tidak berlaku laku atau batal.

Berkenaan dengan khiyar majlis, pendapat para ulama terbagi atas dua bagian, sebagai berikut.

a. Ulama Hanafiyah dan Malikiyah Golongan ini berpendapat bahwa akad dapat menjadi lazim dengan adanya ijab dan Kabul, serta tidak bisa dengan adanya khiyar, sebab Allah SWT, menyuruh untuk menepati janji. Selain itu, suatu akad tidak akan sempurna, kecuali dengan adanya keridaan, sebagaima tersirat dalam AlQur'an, (Q.S An-Nisa: 29)

b. Ulama Syafi'iyah dan Hanabilah Ulama syafi'iyah dan hanabilah berpendapat adanya khiyar majlis. Kedua golongan ini berpendapat bahwa jika pihak yang akan berakad menyatakan ijab dan Kabul, akad tersebut masih termasuk akad yang boleh atau tidak lazim selagi keduanya masih berada di tempat atau belum terpisah badan. Keduanya masih memiliki kesempatan untuk membatalkan, menjadikan atau saling berfikir. Adapun batasan dari kata berpisah diserahkan kepada adat atau kebiasaan manusia dalam bermuamalah (Sahrani dan Abdullah 2011: 7677).

\section{2. Khiyar Syarat.}

Khiyar syarat yaitu penjualan yang di dalamnya disyaratkan sesuatu, baik oleh penjual maupun pembeli, seperti seorang berkata, "saya jual rumah ini 
dengan harga Rp. 100.000.000,00.

Dengan khiyar selama tiga hari

(suhendi 2005: 64). Rasulullah saw.

Bersabda: "kamu boleh khiyar pada setiap yang telah dibeli selama tiga hari tiga malam." (Riwayat Baihaqi).

Pengertian khiyar syarat menurut ulama fiqih adalah "suatu keadaan yang membolehkan salah seorang yang berakad atau masing-masing yang berakad atau selain kedua pihak yang berakad memiliki hak atas pembatalan atau penetapan akad selama waktu yang ditentukan."(Sahrani dan Abdullah 2011: 77).

\section{Khiyar 'Aib (Cacat)}

\section{a. Arti dan landasan khiyar 'aib}

Arti khiyar 'aib (cacat) menurut ulama fiqih adalah "keadaan yang membolehkan salah seorang yang berakad memiliki hak untuk membatalkan atau menjadikannya ketika ditentukan 'aib (kecacatan) dari salah satu yang dijadikan alat tukarmenukar yang tidak diketahui pemiliknya waktu akad.". Dengan demikian, penyebab khiyar 'aib adalah adanya cacat pada barang yang dijualbelikan (ma'qud 'alaih) atau harga (tsaman), karena kurang nilainya atau tidak sesuai dengan maksud, atau orang yang akad tidak meneliti kecacatannya ketika akad berlangsung.

\section{Zakat Dalam Islam.}

Kata zakat berasal dari kata dasar (masdar) dari zaka yang berarti suci, berkah, tumbuh dan terpuji. Senada dengan itu menurut Qardhawi kata zaka berati bertambah dan tumbuh sehingga bisa dikatakan bahwa "tanaman itu zakat", artinya tanaman itu tumbuh (Muhammad, 2007). Sedangkan menurut Ibnu Taymiah "Jiwa orang yang brerzakat itu menjadi bersih dan kekayaannya akan bersih pula, bersih dan bertambah maknanya. Zakat yang merupakan salah satu rukun Islam, hukumnya wajib (fardhu) atas setiap muslim yang telah memenuhi syarat-syarat tertentu. Karena itu zakat adalah ibadah maliyah yang mempunyai dimensi dan fungsi sosial ekonomi dan pemerataan karunia Allah SWT, dan juga merupakan perwujudan solidaritas sosial, pernyataan rasa kemanusiaan dan keadilan.

Secara istilah, kendatipun banyak ulama mengemukakan definisi zakat dengan redaksi yang berbeda-beda antara satu dan yang lainnya, akan tetapi pada prinsipnya sama yaitu bahwa zakat adalah bagian dari harta dengan persyaratan tertentu dari Allah yang telah diwajibkan 
pemiliknya untuk diserahkan kepada yang berhak menerimanya dengan persyaratan tertentu pula. Adapun hubungan antara pengertian zakat secara bahasa dengan pengertin zakat secara istilah sangat nyata dan erat sekali, yaitu bahwa harta yag dikeluarkan zakatnya akan menjadi berkah, tumbuh, berkembang, bertambah, suci dan bersih.

\section{Landasan Zakat Dalam al-Qur'an}

Dalam al-Qur;an terdapat banyak ayat yang menjelaskan tentang kewajiban untuk mengeluarkan zakat. Kata zakat dalam banyak definisi disebutkan tiga puluh kali dalam al-Qur'an, dua puluh tujuh diantaranya disebutkan bersama dalam satu ayat bersama shalat atau Allah menyebutkan kewajiban mendirikan shalat beriringan dengan kewajiban mengeluarkan zakat (Muhammad dalam Zainafi, 2014: 29) Hal ini sesuai dengan beberapa ayat di dalam al-qur'an yang salah satunya adalah (QS al-Baqarah [2] :43) yang terjemahannya

"Dan laksakanlah Shalat, tuaikan zakat dan rukuklah beserta orang-orang yang rukuk"(Departemen Agama RI, 2011:10)

Hal ini menunjukkan bahwa zakat mempunyai kaitan yang sangat erat dengan shalat, meskipun terdapat perbedaan antara keduanya. Zakat adalah suatu ibadah maliyah yang lebih menjurus kepada aspek sosial kemasyarakatan (ijtima'iyah), untuk mengatur hubungan kehidupan manusia dan hubungannya dengan Allah SWT. Sedangkan shalat lebih menjurus kepada kepribadian yang mulia dan bersifat personal (fardhiyah). Oleh karena itu kewajiban mengeluarkan zakat dalam firman Allah SWT ini sama dengan wajibnya kita melaksanakan shalat lima waktu.

Adapun yang menjadi dasar hukum zakat yaitu terdapat dalam firman Allah SWT, yaitu : (QS at-Taubah [9] :103) :

"Ambillah zakat dari harta mereka, guna membersihkan dan mensucikan mereka dan berdoalah untuk mereka. Sesungguhnya do'amu itu (menumbuhkan) ketenteraman jiwa bagi mereka. Dan Allah Maha Mendengar, Maha Mengetahui" (Departemen Agama $\mathrm{RI}, 2011: 352)$.

Ayat ini secara jelas memang tidak menyebutkan jenis harta, nishab dan waktu pengambilan zakat. Oleh karenanya, pada awal penerapan zakat dalam Islam, objek zakat hanya tertuju padakelompok harta sebagaimana yang sudah disebutkan dalam beberapa alqur'an dan al-hadits saja. Adapun pengelompokkannya dikatagorikan dalam empat jenis yaitu : tanam- tanaman dan buah-buahan, hewan ternak, emas, perak 
serta harta perdagangan. Pengelompokkan zakat ini jika kita telaah lebih jauh masih berlaku pada harta saja.

Dalam perkembangan selanjutnya, zakat kemudian dibagi menjadi dua macam yaitu akat nafs/fitrah dan zakat mal. Zakat fitrah merupakan zakat jiwa (zakat al nafs) yaitu kewajiban berzakat bagi setiap individu baik orang dewasa maupun belum dewasa dan dibarengi dengan ibadah puasa (shaum). Adapun zakat mal adalah zakat kekayaan, yang dikelurkan dari kekayaan atau sumber kekayaan itu sendiri. Uang termasuk kekayaan dan pendapatan dari profesi, usaha dan investasi merupakan sumber dari kekayaan. Harta yang wajib dikeluarkan zakatnya adalah emas, perak, hasil pertanian (tanaman dan buah buahan) barang-barang dagangan binatang ternak, barang tambang dan barang temuan.

Landasan Hukum Zakat Hasil Pertanian. Adapun yang menjadi dasar hukum zakat hasil pertannian pertama, terdapat didalam firman SWT (QS alBaqarah[2] : 267).hasil sahamu yang baik baik

"Wahai oramg orang yag beriman, infakkanlah sebagian dari hasil usahamu yang baik baik dan sebagian dari apa yang Kami keluarkan dari bumi untukmu.
Janganlah kau memilih yang buruk untuk kamu keluarkan, padahal kamu sendiri tidak mau mengambilnya melainkan dengan memincingkan mata (enggan) terhadapnya. Dan ketahuilah bahwa Allah Mahakaya dan Maha Terpuji" (Departemen Agama RI, 2011:72-73)

Perintah dalam ayat di atas menunjukkan bahwa mengeluakan zakat dari hasil bumi adalah wajib. Hal ini dapat dipahami dari kalimat "nafkahkanlah" dan klimat "dan sebagian dari apa yang kami keluarkan dari bumi untuk kamu"

Ditegaskan pula dalam ayat tersebut bahwa yang akan dikeluarkan untuk zakat itu adalah yang terbaik, bukan yang jelek jelek apalagi yag paling jelek (HR

Tirmizi dalam Amelia, 2014).

Zakat pertanian merupakan potensi yang sangat besar yang dapat dikembangkan di Indonesia, karena merupakan negara agraris. Dengan melihat kondisi agraris Indoneia ini, secara sederhana dapat disampaikan bahwa yang dimaksud dengan hasil pertanian adalah semua hasil pertanian dan perkebunan yang ditanam masyarakat secara umum seperti jagung, padi, tebu, buah-buahan, sawit, kelapa, kapas,sayur dan sebagainya. Mayoritas fuqaha' berpendapat bahwa zakat hasil pertanian 
dan perkebunan tidak wajib dikeluarkan zakatnya kecuali

telah mencapai nishab tertentu yakni 5 sha'.

Sedangkan bagi hasil bumi yang tidak dapat ditimbangseperti kapas, linen dan sayur maka nishabnya adlah senilai 5 sha' yang setara dengan 200 dirham (HR alBaihaqi dalam Amelia, 2014).

Untuk volume zakat pertanian dan perkebunan ditentukan dengan sistem pengairan yang diterapkan untuk pertanaian maupun perkebunan tersebut yaitu apabila lahan yang irigasinya ditentukan oleh curah hujan, sungai sungai, mata air atau lainnya (lahan tadah hujan) yang diperoleh tanpa mengalami kesulitan, maka persentase zakatnya 10 persen (1/10) dari hasil pertanian. Adapun zakat yang irigasinya menggunakan alat yang beragam (bendungan, irigasi), maka prosentase zakatnya adalah 5 persen $(1 / 20)$, karena kewajiban petani/taggunan untuk biaya pengairan dapat mempengaruhi tingkat nilai asset yang berkembang. Apabila pengairan pada yang setengah periode lahan melalui curah hujan dan setengah periode lainnya melalui irigasi, maka prosentase zakatnya 7,5 persen dari hasil pertanian (al-Wajis al Muqarrim daam Amelia, 2014).
Pemungutan zakat (tak terkecuali zakat pertanian) bukanlah sekedar bantuan makanan sewaktu-waktu untuk sedikit meringankan penderitaan hidup orangorang miskin dan selanjutnya tidak dipehatian lagi bagaiana nasip mereka, ttapi zakat bertujuan menanggulangi kemiskinan. Dengan zakat, Islam menginginkan agar orang orang miskin menjadi berkecukupan selama lamanya dan mengusahakan agar orang orang miskin itu mampu memperbaiki kehidupannya sendiri. Zakat bukan sekedar beberapa liter beras atau beberapa rupiah, namun potensi memperkaya orang orang yang secara ekonomi kurang beruntung. Penyaluran harta zakatpun juga tidak dilakukan secara sembarangan, dalam al-Qur'an secara jelas diterangkan oeh Allah SWT (QS atTaubah [9] :60)

Sesungguhnya zakat itu, hanyalah untuk orang-orang fakir, orang miskin, amil zakat, yang dilunakkan hatinya (mu'allaf), untuk (memerdekakan) hamba sahaya, untuk (memebebaskan) orang yang berhutang, untuk jalan Allah dan untuk orang yang sedang dalam perjalanan, sebagai kewajiban dari Allah. Dan Allah Maha Mengetahui lagi Mahabijaksana" (Departemen Agama RI, 2011:341-342) 
Menurut penjelasan al-Maraghi dalam tafsirnya (At Tadzhib dalam Amelia, 2014) mengenai ayat ini, dikatakan bahwa yang berhak menerima zakat ialah

1. Orang fakir: orang yang amat sengsara hidupnya, tidak mempunyai harta dan tenaga untuk memenuhi penghidupannya

2. Orang miskin : orang yang tidak cukup penghidupannya dan dalam keadaan kekurangan.

3. Pengurus zakat : orang yang diberi tugas untuk mengumpulkan dan membagikan zakat

4. Mualaf : Orang kafir yang ada harapan masuk islam dan orang yang baru masuk islam yang imannya masih lemah

5. Memerdekakan budak : Mencakup juga untuk melepaskan muslim yang ditawan oleh orang kafir

6. Orang berhutang : orang yang berhutang karena untuk kepentingan yang bukan maksiat dan tidak sanggup membayarnya. Adapun orang yang berhutang untuk memelihara peratuan umat Islam dibayar hutangnya itu dengan zakat, walaupun ia mampu membayarnya

7. Pada jalan Allah (Fisabilillah) : yaitu, untuk keperluan pertahanan Islam dan kaum muslimin. Diantara mufasirin ada yang berpendapat bahwa fisabilillah itu mencakup juga kepentingankepentingan umum seperti mendirikan sekolah, rumah sakit, dll

8. Orang yang sedang dalam perjalanan yang bukan maksiat menggalami kesengsaraan dalam perjalanannya.

Kelompok penerima zakat tersebut, sebagaimana yang sudah dijelaskan dalam Al - Qur'an diatas lebih sering dikenal dengan nama Asnaf-8. Hukum penyaluran zakat kepada mereka adalah wajib, karena ayat ini merupakan kelompok ayat yang Qath'i. Jadi penyaluran harta zakat tidak boleh kepada orang selain dalam katagori Asnaf - 8. Dewasa ini Asnaf - 8 sudah tidak sepenuhnya ada, budak saja misalnya, katagori ini sudah lama tidak ada. Katagori fakir, miskin, fisabilillah dan gharimin juga sudah mengalami perluasan makna (H.R Bukhari) dalam Amelia,2014.

\section{Teori Perilaku Beralasan (Theory of Reasoned Action)}

Salah satu teori yang membahas tentang bagaimana sikap dapat mempe-ngaruhi perilaku seseorang atau sekelompok orang pertama adalah teori perilaku beralasan (theory of reasoned action) yang dikemukakan oleh Icek Ajzen dan Martin Fishbein (1980). Teori kedua adalah teori perilaku berencana (theory of 
planned behavior) yang dikembangkan lebih lanjut oleh Ajzen (1987) dari teori yang pertama (Sarwono dan Meinarno, $2009: 90)$.

Dalam teori perilaku beralasan, menurut Fishbein dan Ajzen keputusan untuk melakukan perilaku tertentu merupakan hasil dari proses yang rasional. Beberapa pilihan perilaku dipertimbangkan, konsekwensi dan hasilnya dinilai, kemudian dibuat keputusan untuk melakukan dan tidak melakukan sesuatu (intensi). Dalam hal ini intensi merupakan prediktor utama dari perbuatan atau tindakan yang akan dilakukan orang dalam situasi tertentu. Intensi untuk melakukan dan tidak melakukan perbuatan ditentukan oleh dua determinan dasar, yaitu determinan diri (sikap terhadap perbuatan) dan determinan pengaruh sosial (persepsi seseorang mengenai tekanan sosial yang diperoleh dari orang orang di sekitarnya.

Teori perilaku beralasan tersebut beralku bila memenuhi asumsi. Azwar (2012:11) menyatakan bahwa teori teori perilaku beralasan didasarkan pada asumsi-asumsi a) bahwa manusia umumna melakukan sesuatu dengan cara-cara yang masuk akal, b) manusia mempertimbangkan semua informasi yang ada dan c) secara ekspisit maupun implisit manusia memperhitungkan implikasi tindakan mereka.

\section{Teori Medan (Field Theory)}

Untuk memahami hubungan antara individu dan lingkungannya dapat di-lihat dari beberapa perspektif (seperangkat asumsi dasar tentang hal paling pen-ting yang bisa dipertimbangkan sebagai sesuatu yang bisa digunakan untuk memahami perilaku sosial) yang berkembang, salah satunya adalah Teori Medan (field theory) yang merupakan bagian dari perspektif kognitif (cognitive perspectives).

Teori Medan (field theory) mengkaji perilaku sosial melalui pendekatan konsep "medan" (field) atau "ruang kehidupan" (life space). Menurut Lewin bahwa semua peristiwa psikologis apakah itu berupa tindakan, pikiran, impian, harapan, atau apapun, kesemuanya itu merupakan fungsi dari "ruang kehidupan". Individu dan lingkungan dipandang sebagai sebuah konstelasi yang saling tergantung satu sama lainnya. Artinya "ruang kehidupan" merupakan determinan bagi tindakan, impian, harapan, pikiran seseorang. Bagi Lewin, pemahaman atas perilaku seseorang senantiasa harus dikaitkan dengan konteks - lingkungan di mana perilaku tertentu ditampilkan. Intinya, teori medan berupaya menguraikan 
bagaimana situasi yang ada (field) di sekeliling individu bepengaruh pada perilakunya (Lewin dalam Mustafa, 2009 :

$6)$.

\section{METODOLOGI PENELITIAN}

\section{Jenis Penelitian}

Penelitian ini menggunakan pendekatan kualitatif, karena meneliti realitas, fenomena atau gejala yang bersifat holistik/utuh, kompleks, dinamis dan penuh makna. Penelitian kualitatif adalah penelitian yang bermaksud memahami fenomena tentang apa yang dialami oleh subjek penelitian misalnya perilaku, persepsi, motivasi dan sebagainya secara holistik dan dengan cara deskripsi dalam bentuk kata-kata dan bahasa pada suatu konteks khusus yang alamiah dan dengan memanfaatkan berbagai metode alamiah (Moleong,2018:6). Dengan metode kualitatif diperoleh informasi atau data yang mendalam dan mengandung makna yang sebenarnya dan merupakan suatu nilai dibalik data yang tampak.

\section{Lokasi Penelitian}

Kegiatan penelitian ini dilakukan di Kabupaten Lombok Barat dengan memilih dua Kecamatan yakni Kecamatan Lingsar dan Kecamatan Labuapi. Pemilihan lokasi penelitian ini didasarkan pada beberapa pertimbangan yang mewakili wilayah selatan dan utara Kabupaten Lombok
Barat. Kedua kecamatan ini memiliki pengairan teknis.

\section{Instrumen Penelitian.}

Instrumen utama dalam penelitian ini adalah peneliti sendiri (human instrument). Sebagai human instrument, peneliti dalam kegiatan penelitian berfungsi menetapkan fokus penelitian, menetapkan lokasi penelitian, memilih informan sebagai sumber data, melakukan pengumpulan data, menilai kualitas data, analisis, menafsirkan data dan membuat kesimpulan atas temuan.

\section{Jenis dan Sumber Data}

1. Data primer : Diperoleh secara langsung dari sumbernya, informan secara langsung mempunyai keterkaitan dengan fokus penelitian, yang dapat berupa kata,-kata dan tindakan informan yang diamati dan diwawancarai.

2. Data Skunder : Diperoleh dari Kabupaten Lombok Barat Dalam Angka

\section{Teknik Pengumpulan Data.}

Pengumpulan data primer dilakukan pada kondisi yang alamiah (natural setting). Tehnik pengumpulan data dilakukan dengan cara observasi partisipatif dan wawancara mendalam dan teknik dokumentasi dalam bentuk rekaman suara, rekaman vidio dan foto-foto. 


\section{Pemilihan Informan}

Informan akan diambil dari dua Kecamatan yang ada di Kabupaten Lombok Barat yaitu Kecamatan Lingsar dan Kecamatan Labuapi. Informan dipilih dan ditetapkan selama berada di lapangan, dengan menggunakan teknik "Snowball sampling". Karakteristik informan adalah sebagai berikut : petani yang memiliki usaha tani padi, sudah berkeluarga, pengalaman sebagai petani lebih dari tiga tahun dan menjual padi secara tebasan. Informan tersebut adalah : Sahabudin (SBD), Muzhar (MZR), Subhan $(\mathrm{SBH})$, Abdul Manan (AM), Sudarwan (SDR), Ramli (RML), H. Zainudin (ZDN), Adi Irawan (AI), Sahnim (SHN), Mahsun (MSN)

\section{Analisa Data}

Tehnik analisis kualitatif digunakan untuk menjelaskan data atau fakta empirik yang ditemukan di lapangan. Analisis data dilakukan sejak dimulainya pengumpulan data hingga selesai. Tahapan analisis data adalah sbb :

1. Reduksi Data, pada tahap ini peneliti merangkum, memilih dan memfokuskan pada hal hal yang penting, kemudian dicari tema dan polanya. Dengan demikian data yang telah direduksi dapat memberikan gambaran yang lebih jelas dan mempermudah peneliti untuk melakukan pengumpulan data selanjutnya. Dalam mereduksi data peneliti dipandu oleh tujuan penelitian yang ingin dicapai.

2. Display Data, peneliti menyajikan data yang diperoleh dalam bentuk uraian singkat (teks yang bersifat naratif) dan bagan. Dengan mendisplay data, akan memudahkan peneliti untuk menganalisis apa yang terjadi serta merencanakan langkah selanjutnya berdasarkan apa yang telah dipahami tersebut.

3. Menarik Kesimpulan Peneliti menyimpulkan temuan temuan yang diperoleh selama melakukan penelitian dan didukung oleh bukti bukti yang valid, peneliti menyusun kesimpulan yang berupa deskripsi atas objek studi yang sebelumnya masih samar-samar dan kini menjadi lebih jelas.

\section{PEMBAHASAN}

\section{Usahatani Dan Penjualan Padi Sistim Tebasan.}

Petani di Kabupaten Lombok Barat khususnya di kecamatam Lingsar dan Labuapi melaksanakan usahataninya dalam 2 sampai 3 pola taman. Hal ini 
didukung adanya ketersediaan air sepanjang tahun terutama di kecamatan Lingsar. Air tetap tersedia pada saluranair yang ada di sekat sawah mereka. Kondisi ini berimplikasi kepada ketidak beraturannya waktu memulai usahataninya dan ketidakberaturan pola tanam yang dilakukan petani seperti padipadi-padi, padi-padi-palawija, padipalawija-padi, padi-palawija. Ketidak beraturan ini juga disebabkan tidak berfungsinya peran pekasih secara optimal, sehinggga tidak ada kerjasama dan koordinasi diantara para petani dan pekasih dalam pemanfaatan sumberdaya air di lingkungan mereka.

Petani informan di kecamatan Labuapi dan Lingsar mengusahakan tamanan padi 2-3 kali tanam setahun dengan pola taman yang beragam yaitu padi-padi dan padi-padi-padi. Jenis tanaman padi yang diusahakan adalah jenis IR 64 dan inpari 32 dengan umur panen 110 sampai 116 hari. IR 64 sangat cocok untuk lahan sawah dengan irigasi teknis sepanjang tahun.

Temuan pelaksanaan usahatani padi dan penjualan sistim tebasan pada petani informan sebagai berikut:

\section{SBD.}

Kegiatan usahatani merupakan mata pencaharian pokok bagi SBD yang ditekuninya sejak tahun 2001. SBD sendiri mengelola lahan sawah seluas 40 are, yang berlokasi di Desa Lingsar. Sawah yang digarap merupakan lahan sewa dari Pemerintah Daerah Lombok Barat dengan sewa sebesar Rp. $150.000 /$ are / tahun.

Pelahsanaan usahatani khususnya dalam mengairi sawah, SBD tidak mengaalami kesulitan mendapatkan air, karena ada saluran air di dekat sawahnya, yang berair setiap saat atau sepanjang tahun. Implikasi dari kondisi di atas adalah pola tanam yang dilakukan oleh SBD menjadi tidak teratur, dalam arti kapan saja SBD mau menanam padi tidak ada hambatan . Selama ini SBD menanam padi tiga kali setahun dengan pola tanam padi-padipadi, tanpa pernah mengistirahatkan lahannya.

Alasan SBD menanam hanya padi saja dan tidak tanaman yang lain karena semua petani disini tanam padi, maka SBD juga ikut tanam padi. Perilaku SBD yang terpengaruh oleh petani lainnnya dijelaskan oleh Teori Medan (field theory) atau "ruang kehidupan" (life space) yang dikemukakan oleh Kurt Lewin.

Menurut Lewin bahwa semua peristiwa psikologis apakah itu berupa tindakan, 
pikiran, impian, harapan, atau apapun, kesemuanya itu merupakan fungsi dari "ruang kehidupan". Individu dan lingkungan dipandang sebagai sebuah konstelasi yang saling tergantung satu sama lainnya. Artinya "ruang kehidupan" merupakan juga determinan bagi tindakan, impian, harapan, pikiran seseorang. Bagi Lewin, pemahaman atas perilaku seseorang senantiasa harus dikaitkan dengan konteks - lingkungan di mana perilaku tertentu ditampilkan. Intinya, teori medan berupaya menguraikan bagaimana situasi yang ada (field) di sekeliling individu bepengaruh pada perilakunya (Lewin dalam Mustafa, $2009: 6)$.

Alasan lain selalu menanam padi adalah, karena menurutnya menanam padi praktis, artinya setelah kita tanam kita tidak banyak kegiatan pemelihahaan, tinggal kita menunggu panen saja. Disamping itu harga gabah relatif stabil, tidak seperti tanaman lainnya seperti tembakau dan cabe. Kalau menanam tanaman lain misalnya tembakau disini tidak memungkinkan karena air terlalu banyak.

Perilaku SBD yang selalu menanam padipadi-padi, dijelaskan dalam toeri perilaku beralasan yang dikemukanan oleh Icek Ajzen dan Martin Fishbein
Keputusan untuk melakukan perilaku tertentu merupakan hasil dari proses yang rasional. Beberapa pilihan perilaku dipertimbangkan, konsekwensi dan hasilnya dinilai, kemudian dibuat keputusan untuk melakukan dan tidak melakukan sesuatu (intensi). Dalam hal ini intensi merupakan prediktor utama dari perbuatan atau tindakan yang akan dilakukan orang dalam situasi tertentu. Intensi untuk melakukan dan tidak melakukan perbuatan ditentukan oleh dua determinan dasar, yaitu determinan diri (sikap terhadap perbuatan) dan determinan pengaruh sosial (persepsi seseorang mengenai tekanan sosial yang diperoleh dari orang orang di sekitarnya (Sarwono dan Meinarno, 2009 : 90).

Dalam kegiatan panen, SBD menjual langsung produksi padinya sebelum panen dengan sistim tebasan. Prosesnya adalah padi yang sudah menguning dijual langsung di sawah dengan cara borongan (tebasan) kepada pembeli yang mendatanginya. Dalam pelaksanaan jual beli secara tebasan (borongan) ini, SBD dan pembeli melakukan akad lisan untuk menyepakati harga padi. Sebelum menyepakati harga beli, pembeli melihat langsung kualitas padi ke sawah untuk menaksir kualitas dan kualitas dari padi tersebut. Setelah 
pembeli merasa perhitungannya matang, baru memberikan tawaran harga kepada SDB, selanjutnya terjadi tawah menawar harga padi yang diakhiri dengan kesepakan harga dan cara pembayarannya.

Sistim pembayaran yang dilakukan bahwa SBD menerima uang panjar atau DP (Direct Payment) sebagai tanda jadi kesepakatan. Besaran uang panjer setengah harga dari harga padi. Rentang waktu atau khiyar dari proses panjer hingga pemanenan adalah satu minggu, setelah selesai panen baru sisa panjar dilunasi.

Beberapa alasan SBD melakukan penjualan produksi padi secara langsung dengan sistim tebasqan di tengah sawah: (1) tidak mempunyai lantai jemur tempat menjemur gabahnya, (2) tidak mempunyai biaya untuk mengangkutnya gabah hasil panen dari sawah ke rumah, (3) tidak ada tempat menaruh gabah hasil panen dirumah, (4) ingin mendapatkan uang secepatnya, karena sudah empat bulan tidak pernah melihat /menerima uang dan (5) tidak ada biaya untuk membayar ongkos panen yang relatif mahal (Rp. 50.000 per kuintal gabah kering panen).

\section{MZR.}

Kegiatan usahatani merupakan mata pencaharian pokok bagi MZR yang ditekuninya sejak tahun 1990. Saat ini MZR sendiri mengelola lahan sawah seluas 50 are, yang berlokasi di Dusun Karang Mas Desa Batu Kumbung. Sawah ini merupakan sawah sewa dari Pemerintah Daerah Lombok Barat. Dalam melaksanakan usahaaninya MZR tidak kesulitan mendapatkan air, air tersedia sepanjang tahun. Implikasi dari kondisi di atas adalah pola tanam yang dilakukan oleh MZR tidak teratur, dalam arti kapan saja MZR mau menanam padi tidak ada hambatan . Pola tanam yang dilakukan sepanjang tahun padi-padi-padi.

Pekasih sebagai fihak pengatur air sawah di wilayah ini tidak berfungsi optimal, sehingga air di saluran dimanfaatkan oleh beberapa petani dalam waktu yang bersamaan. Ini berpengaruh pada waktu yang dihabiskan untuk mencukupi air sawah secara optimal. Terjadi kesan saling bebebut air antara petani yang di hulu dan petani yang dihilir.

Kegiatan usahatani padi yang dilakukan MZR dipengaruhi oleh petani lain disekitar sawah mereka yang menanam padi juga. Menurutnya kita mengikuti teman sesama petani. Perilaku MZR yang terpengaruh oleh petani lainnnya dijelaskan oleh Teori Medan 
(field theory) atau "ruang kehidupan" (life space) yang dikemukakan (Lewin dalam Mustafa, $2009: 6$ ) di atas.

Alasan lain mengapa informan selalu menanam padi adalah, karena menanam padi praktis, tidak banyak pemeliharaan, tidak setiap hari bekerja di sawah seperti sayuran dan tembakau. Setelah pemupukan dan penyemprotan, kita menunggu panen saja. Disamping itu harga gabah relatif stabil sekitar $\mathrm{Rp}$ 380.000 sampai Rp 400.000/ kw gabah. Perilaku MZR yang selalu menanam padipadi dan padi, ternyata sudah dijelaskan dalam toeri perilaku beralasan yang dikemukanan oleh Icek Ajzen dan Martin Fishbein (Sarwono dan Meinarno, 2009 : 90) diatas

MZR tidak menjual produksi padi setelah panen tetapi menjual sebelum masa panen dengan sistim tebasan. Proses transaksi tebasan bahwa pembeli datang kesawah memeriksa produk hamparan padi yang telah menguning yang masa panenya satu minggu kedepan. Pembeli memperhitungkan produksi padi yang akan dipoleh. Setelah itu memberikan harga kepada MZR, sehingga terjadi tawar menawar dan diakhiri dengan kesepakatan harga, waktu panen dan pembayaran. MZR menerima uang panjar atau DP (Direct Payment) sebagai tanda jadi kesepakatan transaksi. Kesepakatan ini dilakukan secara lisan (akad lisan) tanpa ada surat atau catatan jual beli. Hal ini dilakukan karena saling percaya diantara meraka dan pembeli telah berkali-kali membeli secara tebasan kepada MZR dan petani lain disekitarnya.

MZR diberikan panjar sebesar Rp.1.000.000,-. Perjanjian pelunasan selama 1 minggu setelah panen. Masa tenggang dari penerimaan uang panjar sampai panen yang dilakukan pembeli merupakan masa khiyar. Bila nantinya tidak terjadi pembelian maka transaksi dibatalkan dan uang muka akan dikembalikan MZR setelah menjual padinya ke pembeli lain. Selama ini pembeli selalu tepat waktu melunasi pembayarannya. MZR menerima semua uang dari hasil penjualan padinya sebesar Rp.9.800.000, yaitu 2,8 ton dikalikan dengan harga Rp.360.000/kwt.

Alasan MZR melakukan penjualan padi secara langsung di tengah sawah. (1) tidak mempunyai lantai jemur tempat menjemur gabahnya, (2) tidak mempunyai biaya untuk mengangkutnya gabah hasil panen dari sawah ke rumah, (3), tidak ada tepat menaruh gabah hasil panen dirumah, (4) ingin mendapatkan uang secepatnya, karena sudah empat bulan tidak pernah melihat /menerima uang (5) 
tidak ada biaya untuk membayar ongkos panen yang relatif mahal (Rp. 50.000 per kuintal gabah kering panen), (6) tidak ada waktu untuk mengurus hasil panen dan (7) kebetulan waktu itu sedang musim hujan, sehingga sangat merepotkan dan akan lebih baik kita jual langsung di tengah sawah.

\section{SBH.}

SBH menekuni usahatani sebagai mata pencaharian pokoknya sejak tahun 1998. Saat ini SBH mengelola lahan sawah seluas 35 are yang berlokasi di Desa Sari Baye, dan diperolehnya atau merupakan hasil menggarap atau sebagai penggarap dari Bapak Rudy yang berdomisili di Kota Mataram. Dalam perjanjian antara SBH dengan pemilik sawah Bapak Rudy, ditentukan atau disepakati bahwa penggarap mendapatkan bagian hasil pertanian sebesar $1 / 3$ bagian dan pemilik mendapatkan hasil $2 / 3$ bagian. Dalam kesepakatan tersebut ditetapkan juga bahwa yang menanggung semua biaya sarana produksi adalah pemilik sawah. Sedangkan penggarap hanya bertugas megkoordinir para pekerja, seperti membajak, menanam, membersihkan rumput, memanen dan menjaga air serta merawat tanaman sampai panen.
SBH tidak kesulitan untuk mendapatkan air sawah yang digarapnya, karena ada saluran air di dekat sawahnya, yang berair setiap saat atau sepanjang tahun. Sama seperti informan sebelunya SBH menanam padi tiga kali setahun (padipadi-padi), tanpa pernah mengistirahatkan lahannya atau ditanami secara terus menerus dengan tanaman sejenis yaitu padi. Menurutnya semua petani disini mengusahakan tanaman padi, kaena itu saya ikut taman padi. Perilaku SBH yang terpengaruh oleh petani lainnnya ternyata sudah dijelaskan oleh Teori Medan (field theory) atau "ruang kehidupan" (life space) (Lewin dalam Mustafa, 2009 : 6) di atas.

Alasan lain SBH selalu menanam padi adalah, karena menanam padi mudah dan praktis, tidak banyak memerlukan pekerjaan, hanya pennaman menggunakan tenaga kerja banyak. Pemupukan dan penyemprotan dapat dialkukan sendiri. Setelah itu kita menunggu panen. Produksi padinya gampang dijual, pembeli datang mencari padi kita. Perilaku SBH yang selalu menanam padi-padi dan padi, ternyata sudah dijelaskan dalam toeri perilaku beralasan yang dikemukanan oleh Icek Ajzen dan Martin Fishbein (Sarwono dan 
Meinarno, 2009 : 90) seperti dikemukakan diatas.

SBH menjual produksi padinya sebelum masa panen secara tebasan (borongan). Proses transaksi secara tebasan sama dengan informan sebelumnya. Akad diakukan secara lisan atas dasar saling percaya. SBH tidak menerima uang panjar, akan tetapi dibayar lunas saat panenan yang dilakukan pembeli.

Beberapa alasan mengapa SBH melakukan penjualan produksi padi sebelum panen dengan sistim tebasan adalah sama dengan informan sebelumnya yaitu SBD, MZR dan SBH terkait dengan tidak ada lantai jemur, biaya angkut dan biaya panen, keterbatasan tempat penyimpanan, ingin mendapat penghasilan cepat dan adanya musim hujan. Alasan lain yang menarik adalah adanya keinginan dari pemilik sawah untuk segera menjual padinya di tengah sawah.

\section{AM.}

Kegiatan usahatani bagi AM yang ditekuninya sejak tahun 2004. Saat ini AM sendiri mengelola lahan sawah seluas 30 are yang berlokasi di Desa Peteluan Indah. Lahan sawah tersebutmerupakan tanah garapan yang dimiliki Bapak Imran yang berdomisili di Kota Mataram. Dalam perjanjian antara AM dengan pemilik sawah Bapak Imran, ditentukan atau disepakati bahwa penggarap mendapatkan bagian hasil pertanian sebesar $1 / 3$ bagian dan pemilik mendapatkan hasil $2 / 3$ bagian. Dalam kesepakatan tersebut ditetapkan juga bahwa yang menanggung semua biaya sarana produksi adalah pemilik sawah. Sedangkan penggarap hanya bertugas megkoordinir para pekerja, seperti membajak, menanam, membersihkan rumput, memanen dan menjaga air serta merawat tanaman sampai panen.

Dalam pelaksanaan usahatani, air tersedia sepanjang tahun, sehingga petani kapanpun dapat mengairi sawahnya. AM mengusahakan padi tiga kali setahundengan pola tanam padi-padipadi, tanpa pernah mengistirahatkan lahannya. AM mengusahakan padi karena semua petani dilingkungannya juga mengusahakan tanaman padi. Perilaku AM yang terpengaruh oleh petani lain ini dijelaskan oleh Teori Medan (field theory) atau "ruang kehidupan" (life space) (Lewin dalam Mustafa, 2009 : 6) yang telah disebutkan sebelumnya.

Selanjutnya alasan lain AM selalu mengusahakan padi adalah, karena menanam padi lebih mudah dan praktis, 
tidak banyak pekerjaan, tidak setiap hari membutuhkan waktu kerja. Pekerjaan sibu hanya pada saat penenaman, pemupukan, penyemprotan dan panenan. Kegiatan ini dilakukan pada waktu tertentu saja. Dari sis harga jual bahwa harga padi relatif setabil. Alasan lain adalah karena keinginan dari pemilik sawah.Perilaku AM yang selalu menanam padi dijelaskan dalam toeri perilaku beralasan yang dikemukanan oleh Icek Ajzen dan Martin Fishbein (Sarwono dan Meinarno, 2009 : 90) seperti diungkap diatas.

AM menjual produksi padi sebelum padi dipanen dengan cara sistim tebasan. Seminggu sebelum panen, pembeli datang memeriksa padi yang akan dijual, selanjutnya pembeli menperkirakan dan menghitung jumlah produksi padi yang akan diperoleh, Selajutnya pembeli melakukan tawar menawar harga dengan AM sampai terjadi kesepakan harga dan membuat akad lisan jual beli secara tebasan secara lisan serta menyepakati waktu panen. Hal yang menarik AM tidak menerima uang panjar atas kesepakan jual beli tebasan tersebut. Pembayaran dilakukan pada saat panen dan disaksikan oleh pemilik sawah.

Beberapa alasan AM melakukan penjualan padi dengan sistim tebasan adalah sama dengan informan sebelumnya yaitu SBD, MZR dan SBH terkait dengan tidak ada lantai jemur, biaya angkut dan biaya panen, keterbatasan tempat penyimpanan, ingin mendapat penghasilan cepat dan adanya musim hujan. Alasan lain yang menarik adalah adanya keinginan dari pemilik sawah untuk segera menjual padinya di tengah sawah untuk segera memperoleh penghasilan.

\section{SDR.}

SDR mengusashakan usahatani sejak tahun 1995. Saat ini SDR mengelola lahan sawah seluas 30 are yang berlokasi di Dusun Punikan Desa Batu Kumbung. Sawahtersebut merupaka warisan dari orang tuanya. SDR melakukan pola tanam tiga kali setahun, yaitu padi-padi-padi. Hal dapat dilakukan karena air tersedia sepanjang tahun. Seperti informan sebelumnya SDR mengusahakan tanaman padi karena semua petani disekitarnya mengusahakan tanaman padi. Perilaku SDR yang terpengaruh oleh petani lainnnya ternyata sudah dijelaskan oleh Teori Medan (field theory) atau "ruang kehidupan" (life space) (Lewin dalam Mustafa, $2009: 6$ ) seperti dijelaskan sebelumnya. 
Alasan mengusahkan padi juga sama seperti informan sebelumnya.yaitu usaha padi mudah dan padi praktis,tidak banyak pekerjaan pada setiap harinya, hanya waktu-waktu tertentu saja membutuhkan banyak tenaga seperti saat taman, pemupukan, pemeliharaan dan penyemprotan serta pemanenan. Perilaku SDR yang selalu menanam padi-padi dan padi, ternyata sudah dijelaskan dalam toeri perilaku beralasan yang dikemukanan oleh Icek Ajzen dan Martin Fishbein (Sarwono dan Meinarno, 2009 : 90) seperti dijelaskan sebelumnya.

Beberapa alasan SDR melakukan penjualan padi dengan sistim tebasan adalah sama dengan informan sebelumnya yaitu SBD, MZR dan SBH terkait dengan tidak ada lantai jemur, biaya angkut dan biaya panen, keterbatasan tempat penyimpanan, ingin mendapat penghasilan cepat dan adanya musim hujan. Alasan lain yang menarik adalahmerasa dirinya repot kalau memanen sendiri karena harus menyediakan konsumsi bagi tukang gabah.

\section{RML.}

Mata pencaharian pokon bagi RML adalah sebagai petani yang ditekuninya sejak tahun 2003. mengelola lahan sawah seluas 50 are, yang berlokasi di Desa
Kuranji Dalang kecamatan Labuapi. Sawah tersebut merupakan warisan dari orang tuanya. Air sawah di daerah ini tersedia sepanjang tahun terutama musin tanam I dan musim tanam II. Musim tanam III kadang ketersediaan air berkurang. Kondisi ketersediaan air sepanjang tahun di kecamatan Labuapi ini tidak sama dengan di kecamatan Lingsar seperti dijekaskan diatas. RML mengusahakan tanaman padi dua kali setahun dan palawija pada musim tanam ketiga, sehingga pola tanamnya padi-padipalawija.

RML mengusahakan tanaman padi dan palawija karena semua petani disekitarnya mengusahakan tanaman yang sama ayitu padi pada musim tanam I dan musim tanam II. Perilaku RML yang terpengaruh oleh petani lainnya dijelaskan oleh Teori Medan (field theory) atau "ruang kehidupan" (life space) (Lewin dalam Mustafa, 2009 : 6) seperti dijelaskan sebelumnya.

RML menjual produksi padinya sebelum masa panen dengan sistim tebasan. Pembeli yang sudah dipesan sebelumnya, datang memeriksa padi disawah bersama RML. Selanjutnya pembeli menghitung perkiraan produksi padi yang akan diperoleh, lalu mengadakan penawaran sampai terjadi 
kesepakan harga dan waktu panen. Kesepakatan yang dibuat padi akan dibayar sesuai dengan kwalitas dari padi tersebut. Jika kwalitas padi bagus harganya 11-14 juta dan jika kwalitas padi jelek maka harga padi 5 - 7 juta. Sistim pembayarannya adalah RML menerima uang panjar atau DP (Direct Payment) sebagai tanda jadi kesepakatan dengan setengah harga dari harga padi. Lima hari setelah selesai panen baru sisa panjar dilunasi.

Alasan RML melakukan penjualan padi dengan sistim tebasan adalah sama dengan informan sebelumnya yaitu SBD, MZR, SBH dan AM terkait dengan tidak ada lantai jemur, tidak memiliki biaya angkut dan biaya panen, keterbatasan tempat penyimpanan, ingin mendapat penghasilan cepat dan tidak mau repot karena musim hujan

\section{Al.}

Usahatani merupakan salah satu mata pencaharian bagi Al yang ditekuninya sejak tahun 2009, juga berprofesi sebagai seorang guru honorer bahasa inggris di salah satu SD yang ada di Desa Kuranji. Al sendiri mengelola lahan sawahnya seluas 24 are yang berlokasi di Desa Kuranji Dalang. Al mengusahakan lahan sawahnya dengan menanam padi 2 kali dan kacangan 1 kali per tahun.

Al mengusahakan tanaman padi dan palawija mengikuti para petani disekitarnya mengusahakan tanaman yang sama yaitu padi pada musim tanam I dan II serta palawija musim tanam III. Perilaku Al yang terpengaruh oleh petani lainnya dijelaskan oleh Teori Medan (field theory) atau "ruang kehidupan" (life space) (Lewin dalam Mustafa, 2009 : 6) dan perilaku Al dalam memilih tanaman padi dijelaskan dalam toeri perilaku beralasan yang dikemukanan oleh Icek Ajzen dan Martin Fishbein (Sarwono dan Meinarno, 2009 : 90) seperti dijelaskan sebelumnya.seperti dijelaskan sebelumnya.

Al menjual produksi padinya langsung di sawah dengan cara tebasan atau borongan kepada pembeli (tengkulak) yang mendatanginya pada saat warna padi sudah menguning. Proses transaksi tebasan sama dengan yang dilakukan RML karena satu desa. Jika kwalitas padi bagus maka harga dari padi Al sebesar 8 juta rupiah sebaliknya jika kwalitas padi buruk maka harganya 2-4 juta rupiah (setengah harga). Al tidak menerima panjar akan tetapi langsung dibayar lunas pada saat terjadi kesepakan 
harga. Satu hari setelah pembayaran tersebu baru dipanen oleh pembeli.

Alasan Al melakukan penjualan padi dengan sistim tebasan adalah sama dengan informan sebelumnya yaitu RML yang tinggal satu desa yang terkait dengan tidak ada lantai jemur, tidak memiliki biaya angkut dan biaya panen, keterbatasan tempat penyimpanan, ingin mendapat penghasilan cepat dan tidak mau repot karena musim hujan.

\section{ZDN.}

Kegiatan pertanian merupakan mata pencaharian pokok bagi ZDN yang ditekuninya sejak tahun 1971. Bertani merupakan pekerjaan warisan turun temurun bagi keluarganya. ZDN mengelola lahan sawahnya seluas 1,24 Ha yang berlokasi di Desa Kuranji Dalang. ZDN mengusahakan lahannya dengan menanam padi dua kali dan kacangan atau jagung satu kali per tahun. Perilaku ZDN yang terpengaruh oleh petani lainnya dijelaskan oleh Teori Medan (field theory) atau "ruang kehidupan" (life space) (Lewin dalam Mustafa, 2009 : 6) dan perilaku Al dalam memilih tanaman padi dijelaskan dalam toeri perilaku beralasan yang dikemukanan oleh Icek Ajzen dan Martin Fishbein (Sarwono dan Meinarno, 2009 : 90) seperti dijelaskan sebelumnya. seperti dijelaskan sebelumnya

ZDN melakukan penjualan padi langsung di sawah dengan cara borongan (tebasan) kepada pembeli (tengkulak) yang mendatanginya untuk melihat sawahnya pada saat warna padi sudah menguning dengan masa panen seminggu lagi. Proses transaksi jual beli tebasan kepada pembeli adalah sama dengan yang dilakukan RML dan Al. Jika kwalitas padi bagus diabayar 38 juta rupiah dan jika kwalitas padi buruk diabayar 25 juta rupiah (setengah harga). ZDN menerima panjar atau DP (Direct Payment) sebesar setengah harga dari harga padi. Rentang waktu atau khiyar dari proses panjar selama 7-10 hari dengan. Pelunasan dikakukan setelah panen dan selama 10 hari sejak panjar. Tansaksi ini dilakukan dengan akad lisan. Pembeli tidak pernah mengurangi harga atau membatalkan kontrak, selalu sesuai dengan kesepakatan awal.

Alasan ZDN melakukan penjualan padi dengan sistim tebasan adalah sama dengan informan sebelumnya yaitu RML dan Al yang tinggal satu desa yang terkait dengan tidak ada lantai jemur, tidak memiliki biaya angkut dan biaya panen, keterbatasan tempat penyimpanan, ingin mendapat penghasilan cepat dan tidak mau repot karena musim hujan. 


\section{SNM}

Usahatani merupakan mata
pencaharian pokok bagi SNM yang
ditekuninya sejak tahun 1999, disamping dia menjual cilok keliling menggunakan sepeda motor. SNM mengelola lahan sawahnya seluas 28 are yang berlokasi di Desa Kuranji Dalang. SNM mengusahakan lahannya dengan menanam padi dua kali dan kacangan dua kali per tahun yang sama dengan informan lainnya di desa Kuranji Dalang. Perilaku SNM yang terpengaruh oleh petani lainnya dijelaskan oleh Teori Medan (field theory) atau "ruang kehidupan" (life space) (Lewin dalam Mustafa, $2009: 6$ ) dan perilaku Al dalam memilih tanaman padi dijelaskan dalam toeri perilaku beralasan yang dikemukanan oleh Icek Ajzen dan Martin Fishbein (Sarwono dan Meinarno, 2009 : 90) seperti dijelaskan sebelumnya.seperti dijelaskan sebelumnya

SNM menjual produksi padinya yang telah menguning kepada pembeli (tengkulak) yang mendatanginya secara tebasan. Transaksi penjualannya sama dengan informan sebelumnya yaitu ZDN. Akad lisan yang disetujui menyatakan jika kwalitas padi bagus maka dibayar seharga 7 samapai 9 juta rupiah sebaliknya jika kwalitas padi buruk dibayar harganya setengah harga bahkan sampai 3 juta rupiah. SNM menerima panjar sebagai tanda jadi jual beli sebesar 3 juta. Rentang waktu atau khiyar dari proses panjar hingga pemanenan selama 7 hari. Pelunasan dilakukan pada saat pemanenan.

Alasan SNM menjual padinya dengan sistim tebasan adalah sama dengan informan sebelumnya yaitu RML, Al dan ZDN yang tinggal satu desa, yaitu tidak ada lantai jemur, tidak memiliki biaya angkut dan biaya panen, keterbatasan tempat penyimpanan, ingin mendapat penghasilan cepat dan tidak mau repot karena musim hujan. Alasan lain SNM sibuk menjual cilok keliling karena bisa memperoleh uang setiap hari bila keliling berjualan.

MSN.

MSN berprofesi sebagai petani sejak tahun 1992, yaitu setahun setelah menikah. Lahan sawah yang diusahakan seluas 47 are yang berlokasi di Desa Kuranji Dalang. Pola tanam yang dilakukan padi-padi-palawija (kacang-kacangan). Hal ini mengikuti petani lain yang ada di desa Kuranji Dalang. Perilaku MSN yang terpengaruh oleh petani lainnya dijelaskan oleh Teori Medan (field theory) atau "ruang kehidupan" (life space) (Lewin 
dalam Mustafa, 2009 : 6) dan perilaku Al dalam memilih tanaman padi dan palawija dijelaskan dalam toeri perilaku beralasan yang dikemukanan oleh Icek Ajzen dan Martin Fishbein (Sarwono dan Meinarno, 2009 : 90) seperti dijelaskan sebelumnya. seperti dijelaskan sebelumnya

MSN menjual produksi padinya sebelum panen dengan sistim tebasan. Proses penjualannya sama dengan informan sebelumnya yaitu ZDN dan SNM. Akad lisan yang disetujui menyatakan jika kwalitas padi bagus maka dibayar seharga 11 samapai 13 juta rupiah sebaliknya jika kwalitas padi buruk dibayar seharga 5 juta rupiah. MSN menerima panjar setengah dari harga padi. Rentang waktu atau khiyar dari proses panjar hingga pemanenan selama 14 hari. Pelunasan dilakukan pada saat pemanenan.

MSN menjual padinya dengan sistim tebasan dengan alasan yang sama dengan informan sebelumnya yaitu RML, Al, ZDN dan SNM yang tinggal satu desa, yaitu tidak ada lantai jemur, tidak memiliki biaya angkut dan biaya panen, keterbatasan tempat penyimpanan, ingin mendapat penghasilan cepat dan tidak mau susah dalam melakukan panenan.

Temuan studi berupa berbagai alasan petani dalam menjual produksi padi secara tebasan seperti telah diungkapkan semua informan memiliki kesamaan dengan hasil penelitian yang dilakukan Cahyani (2010), menyimpulkan faktor yang mempengaruhi transaksi jual beli bawang merah secara tebasan di Desa Sidapurna Kecamatan Dukuh Puri Tegal, yaitu : transaksinya lebih mudah, tidak berbelit-belit, lebih efektif karena tidak perlu repot memanen, serta hemat biaya. Kesamaan hasil studi ini pada pengungkapam konsep trnsaksinya mudah, hemat biaya panen, dan tidak repot (sibuksusah) memanen. Perbedaannya, penelitian ini enemukan bahwa alasan atau faktor pendorong petani menjual produksi padi secara tebasan adalah lebih pada keterbatasan kemampuan petani untuk membiayai panen dan keterbatasan sarana kegiatan pasca panen seperti lanatai jemur dan tempat penyimpanan padi serta keinginan untuk mendaoatan uang hasil penjualan produksi padi.

\section{Jual Beli Padi Sistem Tebasan di lihat dari}

\section{Perspektif Islam}

Dalam jual beli menurut Pasal 21 Kompilasi Hukum Ekonomi Syariah terdapat 13 asas-asas akad (kontrak Syariah) diantaranya. Sukarela, amanah, ikhtiyari, luzum, saling menguntungkan, kesetaraan, transparansi, kemampuan, kemudahan, i'tikad baik, kehalalan, 
kebebasan berekonomi, al-kitabah (tertulis). Hal tersebut wajib diterapkan dalam suatu transaksi untuk tujuan transaksi yang syar'i juga untuk menghindari perselisihan dikemudian hari.

Hasil studi pada semua informan yang melakukan jual beli padi sistem tebasan yang ada di Kabupaten Lombok Barat sudah sesuai dengan semua asas-asas dalam transaksi kecuali asas Al-Kitabah, karena praktik jual beli padi menggunakan alad lisan atas dasar saling percaya. Tidak melakukan akad secara tertulis.

Dalam jual beli terdapat beberapa rukun jual beli yang harus dipenuhi agar jual beli tersebut sah. Rukun dalam jual beli tersebut yaitu : ada orang yang berakad yakni penjual dan pembeli, ada ijab qabul, ada objek transaksi dan ada nilai tukar objek transaksi. Keempat komponen dalam rukun jual beli harus dipenuhi agar jual beli tersebut sah. Apabila salah satu dari rukun tersebut tidak terpenuhi, maka jual beli tersebut menjadi fasid atau rusak.

Jual beli tebasan yang dilaksanakan di Kabupaten Lombok Barat sudah memenuhi syarat dan rukun jual beli dalam Islam. Jual beli dilakukan oleh orang yang berakad, yaitu pihak penjual atau petani dan pihak pembeli atau tengkulak, dalam transaksi tersebut terdapat ijab dan qabul yang diutarakan oleh kedua belah pihak tersebut. Ada objek transaksi yaitu padi dan ada nilai tukar objek transaksi yaitu sejumlah uang yang menjadi nilai tukar objek transaksi.

Jual beli tebasan tersebut juga sudah memenuhi syarat jual beli yaitu dilaksanakan oleh dua orang dewasa yang bertindak sebagai penjual dan pembeli, ijab qabul dilaksanakan dalam satu majelis, harga yang disepakati juga dibayar jelas sekalipun tidak dibayar secara langsung tetapi dibayar bersamaan dengan obyek transaksi yaitu padi yang bijinya sudah menguning atau siap panen.

Dalam Islam, jual beli tebasan di sebut juga jual beli secara Juzaf Dalam jual beli tebasan di Kabupaten Lombok Barat sudah sesuai dengan syarat jual beli secara juzaf. Adapun syarat-syarat jual beli secara juzaf adalah sebagai berikut:

a. Objek transaksi harus bisa dilihat.

b. Penjual dan pembeli tidak mengetahui secara jelas kadar objek jual beli. Pembeli dan penjual padi sistem tebasan memang tidak mengetahui kadar padi secara jelas, maka dari itu padi ditentukan harganya melalui kwalitas dari biji padi.

c. Jual beli dilakukan atas sesuatu yang dibeli secara partai bukan per satuan. 
d.Objek transaksi bisa ditaksir oleh orang yang memiliki keahlian dalam penaksiran.

e.Objek akad tidak boleh terlalu banyak, sehingga sangat sulit ditaksir, namun juga tidak terlalu sedikit, sehingga sangat mudah diketahui kuantitasnya. Objek akad berupa padi yang ditaksir tidak terlalu luas juga tidak terlalu sempit, ukuran yang digunakan dalam pembelian yaitu baik atau buruknya kualitas padi tersebut

f. Tanah yang digunakan sebagai tempat penimbunan objek transaksi haruslah rata, sehingga kadar objek transaksi bisa ditaksir.

g. Tidak diperbolehkan mengumpulkan jual beli barang yang diketahui kadarnya secara jelas, dengan barang yang diketahui kadarnya secara jelas, dalam satu akad. Misalnya, jual beli kurma satu kilo, dikumpulkan dengan apel yang berada dalam satu pohon, dengan satu harga atau dua harga. Dalam hal ini padi tidak diketahui kadarnya secara jelas serta padi ditukar dengan uang, bukan dengan padi yang lain.

Di dalam proses penjualan padi sistem tebasan di Lombok Barat, pada tahap pembayaran padi, menggunakan pola pembayaran dipanjer dahulu baru dilunasi artinya bahwa terdapat masa khiyar, besaran uang panjer yang diberikan petani oleh pembeli setengah dari harga padi dengan masa khiyar 5-14 hari. Dari hal itu peneliti menyimpulkan bahwa waktu khiyar dari proses panjer hingga pemanenan tidak sesuai dengan waktu khiyar yang disyariatkan oleh islam, dimana dikatakan dalam sabda Rasulullah SAW "kamu boleh khiyar pada setiap yang telah dibeli selama tiga hari tiga malam." (Riwayat Baihaqi). Akan tetapi setiap penjualan padi sistem tebasan di Kabupaten Lombok Barat, selama waktu khiyar, padi tidak pernah mengalami kerusakan yang mengakibatkan pembeli mengurangi harga padi atau membatalkan kontrak. Dari 10 informan yang peneliti wawancarai 7 informan yang menggunakan pola pembayaran dipanjer dahulu sebagai pengikat kontrak dan dilunasi saat panen.

Kemudian di dalam pengambilan suatu tindakan atau keputusan seseorang yang dalam hal ini adalah penjualan padi secara tebasan, pasti memiliki alasan yang rasional untuk melakukannya. Prilaku informan ternyata sesuai dengan "teori perilaku beralasan" yang dikemukakan oleh Fishbein dan Ajzen yaitu : "keputusan untuk melakukan perilaku tertentu merupakan hasil dari proses yang rasional. Beberapa pilihan perilaku dipertimbangkan, konsekwensi dan 
hasilnya dinilai, kemudian dibuat keputusan untuk melakukan dan tidak melakukan sesuatu (intensi)".

Praktik Pembayaran Zakat Pertanian.

1. SBD.

Umumnya kondisi lahan pertanian yang ada di wilayah Desa Lingsar sebahagian besar ber pengairan tehnis dengan pola tanam padi, padi dan padi. Apabila kondisi pegairan ini di hubungkan dengan besarnya zakat pertanian yang dikeluarkan, maka SBD seharusnya mengeluarkan zakat pertanian padi sebesar 5 persen dari jumlah produksi gabah kering panen. Setelah dilakukan perhitugan antara produksi yang di dapatkan dan biaya biaya yang dikeluarkan, ternyata SBD mendapatkan hasil bersih sebesar Rp. 1.500.000, selama satu kali musim tanam. Dengan demikian besarnya zakat pertanian yang dikeluarkan adalah sebesar 2,5 persen dikalikan dengan Rp. 1.500.000,- = Rp. 37.500,Jumlah ini sudah diberikan kepada fakir dan miskin dikalangan keluarga dekatnya.

Menurut peneliti, perilaku SBD yang mengeluarkan zakat pertanian sebesar 2,5 persen dari hasil penjualan gabah tidak sesuai dengan ketentuan zakat pertanian meurut Islam. Menurut ketentuan Islam besarnya zakat pertanian dengan sawah yang yang menggunakan irigsi tehnis adalah sebesar 5 persen dari jumlah produksi.

\section{MZR.}

Kondisi lahan pertanian yang ada di wilayah Dusun Karang Mas Desa Batu Kumbung sebahagian besar ber pengairan tehnis dengan pola tanam padi, padi dan padi. Apabila kondisi pegairan ini di hubungkan dengan besarnya zakat pertanian yang dikeluarkan, maka MZR seharusnya mengeluarkan zakat pertanian padi sebesar 5 persen dari jumlah produksi gabah kering panen.

Pada saat itu hasil panen Muzhar adalah 2,8 ton gabah kering panen. Menurut ketentan Islam besarnya zakat pertanian yang harus di bayar oleh Muzhar adalah sebesar 5 pesen dari 2.8 ton, yaitu sebesar $140 \mathrm{~kg}$ gabah kering panen. Akan tetapi setelah Muzhar menerima pembayaran gabah, muzhar tidak mengeluarkan zakat pertanian.

3. SBH.

Kondisi lahan pertanian yang ada di wilayah Desa Sari Baye sebahagian besar ber pengairan tehnis dengan pola tanam padi, padi dan padi. Apabila kondisi pegairan ini di hubungkan dengan besarnya zakat pertanian yang 
dikeluarkan, maka SBH seharusnya mengeluarkan zakat pertanian padi sebesar 5 persen dari jumlah produksi gabah kering panen.

Pada saat itu hasil panen Subhan adalah 1,8 ton gabah kering panen. Menurut ketentan Islam besarnya zakat pertanian yang harus di bayar adalah sebesar 5 persen dari jumlah 1,8 ton, yaitu sebesar $90 \mathrm{~kg}$ gabah kering panen. Akan tetapi setelah terjadi pembayaran gabah, uang hasil penjualan dibagi menjadi tiga bagian, 1/3 untuk Subhan dan 2/3 untuk pemilik sawah. Menurut informan tidak ada pembicaran mengenai siapa yang membayar zakat pertanian. Subhan tidak mengeluarkan zakat pertanian dengan alasan saya hanya sebagai penggarap.

\section{AM.}

Kondisi lahan pertanian yang ada di wilayah Desa Peteluan Indah sebahagian besar ber pengairan tehnis dengan pola tanam padi, padi dan padi,tetapi juga dapat juga ditanami padi, padi dan palawija. Apabila kondisi pegairan ini di hubungkan dengan besarnya zakat pertanian yang dikeluarkan, maka AM seharusnya mengeluarkan zakat pertanian padi sebesar 5 persen dari jumlah produksi gabah kering panen.
Proses penjualan padi oleh AM adalah sebagai berikut : pertama Abdul Manan menawarkan padi yang belum di panen ke pembeli. Setelah dilihat oleh calon pembeli,langsung terjadi tawar menawar antara AM dengan calon pembeli. Tidak ada batasan harga per kuintal dan berapa jumlah produksi, langsung terjadi tawar menawar. Dengan disaksikan oleh pemilik sawah AM menjual padi yang masih belum dipanen seharga Rp. 6.200.000.

Menurut ketentan Islam, mestinya gabah yang di panen atau dijual harus ditimbang sebelumnya untuk menentukan besarnya zakat pertanian yang harus di keluarkan, yang besarnya adalah 5 persen. Akan tetapi setelah terjadi pembayaran gabah, uang hasil penjualan dibagi menjadi tiga bagian, 1/3 untuk Abdul Manan dan 2/3 untuk pemilik sawah. Menurut informan tidak ada pembicaran mengenai siapa yang membayar zakat pertanian. Abdul Manan mnerima bagian pada saat itu sebesar Rp.2000.000, dan tidak mengeluarkan zakat pertanian dengan alasan saya hanya sebagai penggarap.

5. SDR.

Kondisi lahan pertanian yang ada di wilayah Dusun Punikan Desa Batu Kumbung sebahagian besar ber 
pengairan tehnis dengan pola tanam padi, padi dan padi. Apabila kondisi pegairan ini di hubungkan dengan besarnya zakat pertanian yang dikeluarkan, maka SDR seharusnya mengeluarkan zakat pertanian padi sebesar 5 persen dari jumlah produksi gabah kering panen.

Proses penjualan padi oleh SDR adalah sebagai berikut : pertama Sudarwan menawarkan padi yang belum di panen ke pembeli. Setelah dilihat oleh calon pembeli, baru ditentukan harga gabah secara keseluruhan ang ada di tengah sawah. Pada saat itu harga yang disepakati adalah sebesar $\mathrm{Rp}$. Rp.7.500.000,- . Menurut ketentuan Islam besarnya zakat pertanian yang harus di bayar oleh Sudarwan adalah sebesar 5 pesen dari jumlah produksi yang di dapat. Akan tetapi karena, gabah di jual di tegah sawah, maka Sudarwan kesulitan dalam menentukan berapa besar zakat yang harus dikeluarkan. Akan tetapi setelah Sudarwan menerima pembayaran gabah, Sudarwan tidak mengeluarkan zakat pertanian.

\section{RML.}

Umumnya kondisi lahan pertanian yang ada di wilayah Desa Kuranji Dalang sebahagian besar ber pengairan tehnis dengan pola tanam padi, padi dan palawija. Apabila kondisi pegairan ini di hubungkan dengan besarnya zakat pertanian yang dikeluarkan, maka RML seharusnya mengeluarkan zakat pertanian padi sebesar 5 persen dari jumlah produksi gabah kering panen. Setelah dilakukan perhitugan antara produksi yang di dapatkan dan biaya biaya yang dikeluarkan, ternyata RML mendapatkan hasil bersih sebesar Rp. 12.500.000, selama satu kali musim tanam. Dengan demikian besarnya zakat pertanian yang dikeluarkan adalah sebesar 5 persen dikalikan dengan Rp. 12.500.000,- = Rp. 625.000,- Jumlah ini sudah diberikan kepada fakir dan miskin dikalangan keluarga dekatnya.

Menurut peneliti, perilaku RML yang mengeluarkan zakat pertanian sebesar 5 persen dari hasil penjualan gabah tidak sesuai dengan ketentuan zakat pertanian meurut Islam. Menurut ketentuan Islam besarnya zakat pertanian dengan sawah yang yang menggunakan irigsi tehnis adalah sebesar 5 persen dari jumlah produksi gabah kering panen.

\section{Al.}

Umumnya kondisi lahan pertanian yang ada di wilayah Desa Kuranji Dalang sebahagian besar ber pengairan tehnis dengan pola tanam padi, padi 
dan palawija. Apabila kondisi pegairan ini di hubungkan dengan besarnya zakat pertanian yang dikeluarkan, maka Al seharusnya mengeluarkan zakat pertanian padi sebesar 5 persen dari jumlah produksi gabah kering panen. Setelah dilakukan perhitugan antara produksi yang di dapatkan dan biaya biaya yang dikeluarkan, ternyata Al mendapatkan hasil bersih sebesar Rp. 5.000.000, selama satu kali musim tanam. Dengan demikian besarnya zakat pertanian yang dikeluarkan adalah sebesar 2,5 persen dikalikan dengan Rp. 5.000.000,- = Rp. 125.000,Jumlah ini sudah diberikan kepada fakir dan miskin dikalangan keluarga dekatnya.

Menurut peneliti, perilaku Al yang mengeluarkan zakat pertanian sebesar 2,5 persen dari hasil penjualan gabah tidak sesuai dengan ketentuan zakat pertanian meurut Islam. Menurut ketentuan Islam besarnya zakat pertanian dengan sawah yang yang menggunakan irigsi tehnis adalah sebesar 5 persen dari jumlah produksi.

\section{ZDN.}

Kondisi lahan pertanian yang ada di wilayah Desa Kuranji Dalang sebahagian besar ber pengairan tehnis dengan pola tanam padi, padi dan palawija. Apabila kondisi pegairan ini di hubungkan dengan besarnya zakat pertanian yang dikeluarkan, maka ZDN seharusnya mengeluarkan zakat pertanian padi sebesar 5 persen dari jumlah produksi gabah kering panen dengan asumsi bahwa produksi yang diperoleh tidak kurang dari 1250 kg gabah kering panen.

$$
\text { Umumnya kondisi lahan }
$$
pertanian yang ada di wilayah Desa Kuranji Dalang sebahagian besar ber pengairan tehnis dengan pola tanam padi, padi dan palawija. Apabila kondisi pegairan ini di hubungkan dengan besarnya zakat pertanian yang dikeluarkan, maka ZDN seharusnya mengeluarkan zakat pertanian padi sebesar 5 persen dari jumlah produksi gabah kering panen. Setelah dilakukan perhitugan antara produksi yang di dapatkan dan biaya biaya yang dikeluarkan, ternyata ZDN mendapatkan hasil bersih sebesar Rp. 36.000.000,selama satu kali musim tanam. Dengan demikian besarnya zakat pertanian yang dikeluarkan adalah sebesar 5 persen dikalikan dengan Rp. 36.000.000,- = Rp. 1.800.000,- Jumlah ini sudah diberikan kepada fakir dan miskin dikalangan keluarga dekatnya, juga diberikan kepada 
penghulu dan para Ustadz yang ada di sekitar desanya.

Menurut peneliti, perilaku ZDN yang mengeluarkan zakat pertanian sebesar 5 persen dari hasil penjualan gabah tidak sesuai dengan ketentuan zakat pertanian meurut Islam. Menurut ketentuan Islam besarnya zakat pertanian dengan sawah yang yang menggunakan irigsi tehnis adalah sebesar 5 persen dari jumlah produksi gabah kering panen. Akan tetapi karena gabahnya dijual secar tebasan, maka ZDN tidak bisaa mengetahui berapa jumlah gabah yang dihasilkan.

\section{SNM}

Umumnya kondisi lahan pertanian yang ada di wilayah Desa Kuranji Dalang sebahagian besar ber pengairan tehnis dengan pola tanam padi, padi dan palawija. Apabila kondisi pegairan ini di hubungkan dengan besarnya zakat pertanian yang dikeluarkan, maka SNM seharusnya mengeluarkan zakat pertanian padi sebesar 5 persen dari jumlah produksi gabah kering panen. Setelah dilakukan perhitugan antara produksi yang di dapatkan dan biaya biaya yang dikeluarkan, ternyata SNM mendapatkan hasil bersih sebesar Rp. 10.000.000,- selama satu kali musim tanam. Dengan demikian besarnya zakat pertanian yang dikeluarkan adalah sebesar 5 persen dikalikan dengan Rp. 11.000.000,- = Rp. 500.000,- Jumlah ini sudah diberikan kepada fakir dan miskin dikalangan keluarga dekatnya.

Menurut peneliti, perilaku SNM yang mengeluarkan zakat pertanian sebesar 5 persen dari hasil penjualan gabah tidak sesuai dengan ketentuan zakat pertanian meurut Islam. Menurut ketentuan Islam besarnya zakat pertanian dengan sawah yang menggunakan irigsi tehnis adalah sebesar 5 persen dari jumlah produksi gabah kering panen.

\section{MSN}

Umumnya kondisi lahan pertanian yang ada di wilayah Desa Kuranji Dalang sebahagian besar ber pengairan tehnis dengan pola tanam padi, padi dan palawija. Apabila kondisi pegairan ini di hubungkan dengan besarnya zakat pertanian yang dikeluarkan, maka MSN seharusnya mengeluarkan zakat pertanian padi sebesar 5 persen dari jumlah produksi gabah kering panen. Setelah dilakukan perhitugan antara produksi yang di dapatkan dan biaya biaya yang dikeluarkan, ternyata MSN mendapatkan hasil bersih sebesar Rp. 11.500 .000 , selama satu kali musim tanam. Dengan demikian besarnya zakat pertanian yang dikeluarkan 
adalah sebesar 5 persen dikalikan dengan Rp. 12.500.000,- = Rp. 575.000,- Jumlah ini sudah diberikan kepada fakir dan miskin dikalangan keluarga dekatnya.

Menurut peneliti, perilaku MSN yang mengeluarkan zakat pertanian sebesar 5 persen dari hasil penjualan gabah tidak sesuai dengan ketentuan zakat pertanian meurut Islam. Menurut ketentuan Islam besarnya zakat pertanian dengan sawah yang yang menggunakan irigsi tehnis adalah sebesar 5 persen dari jumlah produksi gabah kering panen.

\section{Kesimpulan.}

KESIMPULAN DAN SARAN.

1. Alasan petani menjual padinya dengan sistim tebasan, adalah karena :

a. Tidak mempunyai lantai jemur tempat menjemur gabahnya

b. Tidak mempunyai biaya untuk mengangkutnya gabah dari sawah ke ru- mah.

c. Tidak ada tepat menaruh gabah hasil panen dirumah.

d. Ingin mendapatkan uang secepatnya, karena sudah empat bulan tidak pernah melihat /menerima uang.

e. Tidak ada biaya untuk membayar ongkos panen yang relatif mahal (Rp. 50.000 per kuintal gabah kering panen), f. Tidak ada waktu untuk mengurus hasil panen,

g. Kebetulan saat ini sedang musim hujan, sehingga sangat merepotkan,

h. Keinginan dari pemilik sawah untuk menjual gabahnya secara langsung ke pembeli.

2.Semua informan yang belum mengeluarkan zakat pertanian secara syar'i. Alasan nya adalah karena mereka sebagai penggarap, mereka menjual gabahnya secara langsung di tengah sawah serta mereka mengeluarkn zakat sebesar lima persen dari hasil penjualn gabah dalam bentuk uang.

\section{Saran.}

1. Diharapkan kepada para petani yang akan menjual padi sistem tebasan, agar menimbang terlebih dahulu gabahnya sebelum dijual untuk memudahkan

penetapan besarnya zakat pertanian yang dikeluarkan.

2. Diharapkan kepada para tokoh agama untuk melakukan penyuluhan tentang sarat, rukun dan hukum zakat pertanian, supaya para petani memahaminya.

3. Diharapkan dari hasil penelitian ini dapat dijadikan masukan bagi Pemerintah Wilayah Kabupaten 
Lombok Barat untuk kebijakan tata pemerataan dan distribusi yang kelola zakat, infaq dan sadaqah. berkeadilan.

Artinya mulai menghidupkan kembali

kegiatan ZIS di tingkat Desa untuk

\section{DAFTAR PUSTAKA}

2011, Al-Quran dan Terjemahannya, Penerbit Pustaka Agung, Surabaya,

Ariani, Zainafi, 2014, Pemahaman dan Implementasi Zakat Infaq Shadaqah (ZIS) Dikalangan

Pegawai Negeri ipil (PNS) dan Kesejahteraan Keluarganya di Kabupaten Lombok Timur, Thesis.

Aziz, Abdul. , 2013. Etika Bisnis Perspektif Islam, Bandung: Alfabeta.

Azwar, Saifuddin, 2012,Sikap Manusia, teori dan pengukurannya, Cetakan XVII, Yogjakarta, Pustaka Pelajar

Daud Ali, MuhammD, 2006, Sistem Ekonomi Islam : Zakat dan Wakaf, Penerbit Jakarta : UI Press.

Dedi Iskandar, 2009, "Pengelolaan Zakat Pertanian di Jorong Sawah Sundi Kecamatan Bukit Sundi Kabupaten Solok"

Djuwaini,Dimyauddin, 2010. Pengantar Fiqh Muamalah. Yogyakarta: Pustaka Pelajar.

Fakhruddin, 2008, Fiqh dan Menejemen Zakat di Indonesia, Penerbit Yogjakarta: UINMaslang Press

Huda, Miftahul. 2013. Aspek Ekonomi Dalam Syariat Islam, NTB: Lembaga Konsultasi dan bantuan Hukum (LKBH) IAIN Mataram.

Kuswara, 2006. Dasar Gagasan dan Praktik Tanam Padi Metode SRI, Tabloid Pertanian Edisi No.30/Agustus Tahun IV/2006.

Manan, Abdul.2012.Hukum Ekonomi Syariah: Dalam PerspektifKewenangan Peradilan Agama, Jakarta: Kencana PrenadaMedia Group.

Mardani, 2012.Fiqih Ekonomi Syariah: fiqih Muamalah. (Edisi ke-1).Jakarta: Prenadamedia Group.

Muhammad, 2007, Aspek Hukum dalam Muamalah, penerbit Graha Ilmu Yogjakarta Mustafa, Hasan, 2007, Perspektif Dalam Perilaku Sosial,Makalah 
Moleong, J. Lexy, 2007, Metodologi Penelitian Kualitatif, Edisi, Revisi, Penebit Remaja Rosdakarya, Bandung.

Nila Amelia, 2014, Efektivitas Distribusi Zakat Pertanian dalam Meningkatkan Perekonomian Masyarakat (Studi Kasus di Nagari Saruaso Kecamatan Tanjung Emas Kabupaten Tanah Datar.

Profil Desa Kuranji Dalang, Kecamatan Labuapi, Kabupaten Lombok Barat-NTB

Setiawan, Agus Nogroho, 2011, Sistim Pertanian Indonesia Tinggalkan Kearifan Lokal, Makalah, http//news 228-detail-sistem-pertanian-indonesia-tinggalkankearifan-lokal.htm

Syafiudin, Ahmad. 2007. Tinjauan Fiqih Muamalah Terhadap Pelaksanaan Jual Beli Hasil Pertanian Dengan Cara Borongan (Studi Kasus Di Desa Kolomayan Wonodadi Blitar), Skripsi. Malang: Universitas Islam Negeri Maulana Malik Ibrahim Malang.

Syafi'i, Rachmat. 2001. Figh Muamalah, Bandung: CV. Pustaka Setia.

Sarwono,Sarlito W, 2009 dan Eko A, Meinarmo, 2009.Psikologi Sosial, Penerbit Salemba Humanika, Jakarta.

Veithzal Rivai dan Antoni Nizar Usman.2012.Islamic Economics AndFinance : Ekonomi dan Keuangan Islam Bukan Alternatif, tetapi Solusi, Jakarta : Gramedia Pustaka Utama.

Wardi Muslich, Ahmad. 2010. Figh Muamalat,Jakarta : Amzah.

Zadjuli, Suroso Imam, 2006, Makalah Seminar Evaluasi Ekonomi Syari'ah 2005 dan Outlook 2006 di Ballroom Hotel Hilton Surabaya Diselenggarakan oleh CIEBERD Universitas Airlangga Surabaya.

2007, "Reformasi Ilmu Pengetahuan Dan Pembangunan Masyarakat Madani", Journal of Islamic Business and Economics, Ekonomika dan Bisnis Islam) Fakultas Ekonomi Universitas Gajah 